Review

\title{
Acute Effects of Nutritive and Non-Nutritive Sweeteners on Postprandial Blood Pressure
}

\author{
Hung Pham ${ }^{1}$, Liza K. Phillips ${ }^{1,2}$ and Karen L. Jones ${ }^{1,2, *(\mathbb{C}}$ \\ 1 NHMRC Centre of Research Excellence in Translating Nutritional Science to Good Health, Adelaide Medical \\ School, The University of Adelaide, Adelaide, SA 5000, Australia \\ 2 Endocrine and Metabolic Unit, Royal Adelaide Hospital, Adelaide, SA 5000, Australia \\ * Correspondence: karen.jones@adelaide.edu.au; Tel.: +61-8-8313-7821
}

Received: 24 June 2019; Accepted: 20 July 2019; Published: 25 July 2019

\begin{abstract}
Postprandial hypotension (PPH) is under-recognised, but common, particularly in the elderly, and is of clear clinical importance due to both the independent association between PPH and an increase in mortality and lack of effective management for this condition. Following health concerns surrounding excessive consumption of sugar, there has been a trend in the use of low- or non-nutritive sweeteners as an alternative. Due to the lack of literature in this area, we conducted a systematic search to identify studies relevant to the effects of different types of sweeteners on postprandial blood pressure (BP). The BP response to ingestion of sweeteners is generally unaffected in healthy young subjects, however in elderly subjects, glucose induces the greatest decrease in postprandial BP, while the response to sucrose is less pronounced. The limited studies investigating other nutritive and non-nutritive sweeteners have demonstrated minimal or no effect on postprandial BP. Dietary modification by replacing high nutritive sweeteners (glucose, fructose, and sucrose) with low nutritive (D-xylose, xylitol, erythritol, maltose, maltodextrin, and tagatose) and non-nutritive sweeteners may be a simple and effective management strategy for PPH.
\end{abstract}

Keywords: postprandial hypotension; nutritive sweeteners; non-nutritive sweeteners; glucose; fructose; sucrose; D-xylose; xylitol; erythritol; maltose; maltodextrin; tagatose

\section{Introduction}

The consumption of nutritive sweeteners has dramatically increased worldwide due to increasing urbanisation and beverage promotion [1]. Nutritive sweeteners commonly found in foods and beverages include glucose, fructose and sucrose [2,3]. More recently, some other sweeteners like D-xylose, xylitol, erythritol, maltose, maltodextrin, stevia and tagatose with lower energy have been used $[2,3]$. There has been a long history of debate as to the detrimental health effects of sucrose, glucose, and more recently, fructose, particularly when consumed in excess. The effects of both nutritive and non-nutritive sweeteners on cardiovascular risk factors, including blood pressure (BP), have been extensively investigated, however, less is known about their specific effects in the postprandial state. Postprandial hypotension (PPH), a fall in systolic BP (SBP) $\geq 20 \mathrm{mmHg}$ after a meal, is now recognized as a frequent and important clinical problem, with a reported prevalence of $24-48 \%$ in the healthy elderly [4]. PPH is particularly common in conditions associated with autonomic dysfunction e.g., in type 2 diabetes mellitus (T2DM) ( 40\%) [4,5] and Parkinson's disease (PD) $(40-100 \%)[4,5]$. Patients with PPH are at increased risk of syncope and falls [6], and importantly the presence of PPH has been established as an independent predictor of increased mortality [7]. In a cohort study of 401 elderly ambulatory hypertensive subjects, 292 (72.8\%) were found to have PPH, and over a 4 year period, 34 died from cardiovascular disease; the post-breakfast BP fall was the strongest predictor of mortality in this cohort [8]. In a 29-month prospective study of 499 nursing home residents, the maximum 
fall in postprandial BP was shown to be an independent predictor of subsequent falls, syncope, new cardiovascular events (myocardial infarction and stroke) and total mortality [9].

The pathophysiology of PPH is multifactorial and incompletely understood, however, it involves the interplay between autonomic and neural mechanisms, including the release of gut hormones, which are influenced by meal composition, gastric distension, and small intestinal nutrient delivery [4]. After a meal, there is a doubling of the superior mesenteric artery (SMA) blood flow [5] and in healthy young individuals with intact baroreflex function, the increase in splanchnic blood flow is accompanied by concomitant increases in heart rate (HR), peripheral vascular resistance, stroke volume and cardiac output [10]. In patients with $\mathrm{PPH}$, these compensatory responses are inadequate [5]. The postprandial fall in BP is greater when gastric emptying is more rapid [11-13], whereas gastric distension attenuates the fall in BP in both healthy young and older participants [11-13]. The macronutrient composition of the meal is also an important determinant of postprandial BP, with carbohydrate inducing an earlier fall in BP compared with protein and fat [14] (Figure 1). The interaction between nutrients and the small intestine stimulates the secretion of the incretin hormones, glucagon-like peptide-1 (GLP-1) from L-cells and glucose-dependent insulinotropic polypeptide (GIP) from K-cells [15]. GLP-1 stimulates insulin secretion, inhibits glucagon secretion and slows gastric emptying $[16,17]$. Acute infusion of GLP-1 has been shown to attenuate the fall in BP and increases SMA blood flow following oral [16] or intraduodenal (ID) glucose [16,18]. In contrast, exogenous GIP has been shown to increase the rate of gastric emptying [19], although results have been conflicting [20] and there have been no studies directly investigating the effect of GIP on postprandial BP. A reduction in BP is not observed following intravenous administration of glucose [21], which is a substantial stimulus to insulin secretion, suggesting that insulin by itself if not an important mediator of PPH. Furthermore, PPH is seen in the absence of insulin secretion i.e., in those with type 1 diabetes [22].
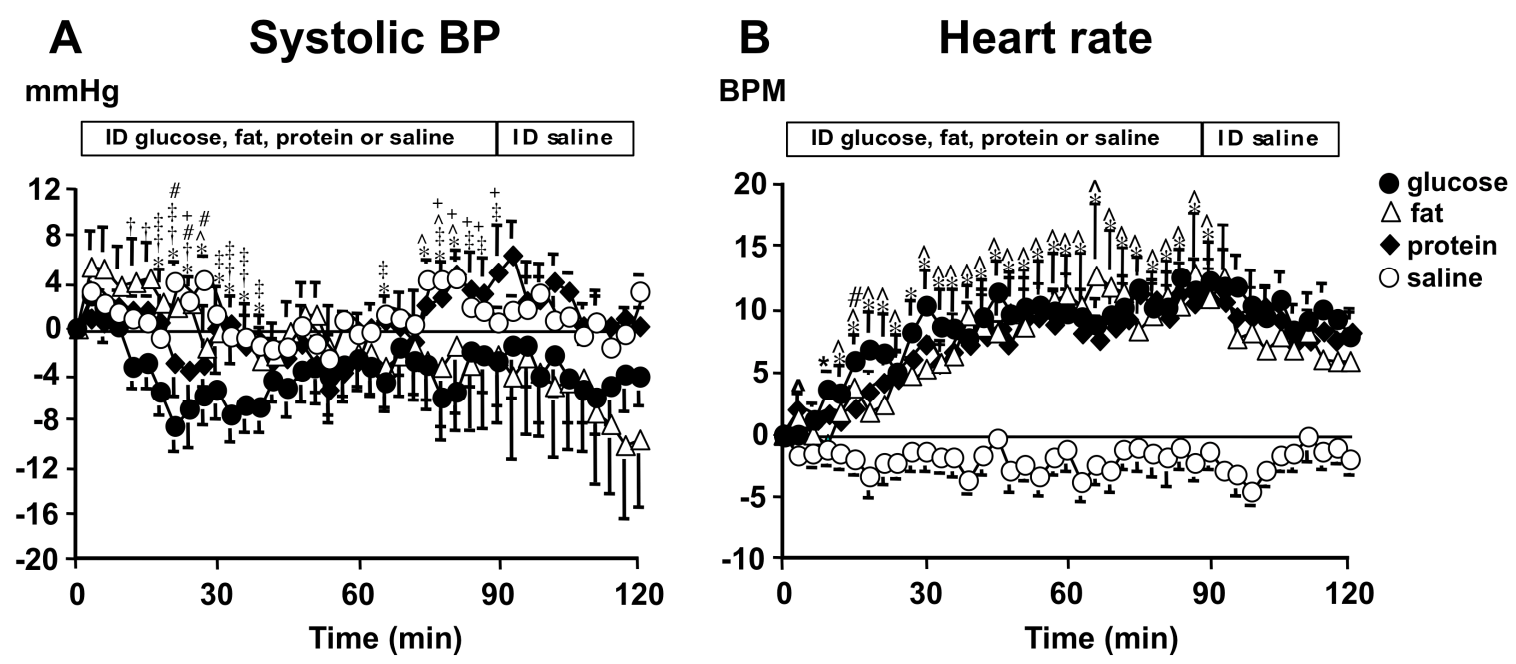

Figure 1. Changes from baseline in (A) Systolic blood pressure (BP) and (B) Heart rate in eight healthy older participants in response to intraduodenal (ID) infusion of glucose, fat, protein, and saline. Values are means \pm SEM. ${ }^{*} p<0.05$ for glucose compared with saline; $+p<0.05$ for glucose compared with fat; $\ddagger p<0.0001$ for glucose compared with protein; ${ }^{\wedge} p<0.05$ for fat compared with saline; $\# p<0.05$ for protein compared with saline; $+p<0.05$ for fat compared with protein [14]. BPM $=$ beats per minute.

In recent years, due to several negative health effects from the excessive consumption of added sugar, a variety of non-nutritive artificial sweeteners have increasingly been used in the food industry as an alternative to sugar among people of all ages, particularly directed to the obese and those with diabetes, with the aim of reducing energy intake and minimising the risk of obesity, diabetes and cardiovascular disease [3,23]. Beverages account for the highest percentage of non-nutritive sweetener utilisation in the world [24,25]. In the United States, non-nutritive sweeteners were used in up to $32 \%$ and $19 \%$ of beverages consumed by adults and children respectively from 2007 to 2010 [26]. In 2018, 
the American Heart Association suggested that short-term use of "non-nutritive" sweeteners instead of "nutritive sweeteners" can reduce caloric intake in the management of excess weight and obesity [27].

There are some differences between regulatory bodies regarding approval of nutritive and non-nutritive sweeteners. The six non-nutritive sweeteners approved by Food and Drug Administration (FDA) as food additives in the United States include sucralose, Acesulfame-K, aspartame, saccharin, neotame and advantame $[2,28,29]$. Stevia $[29,30]$ has not received official FDA approval but has been rated as generally recognized as safe (GRAS) and is being increasingly used as a non-nutritive sweetener [31]. Maltitol similarly has not received official FDA approval, but may be used in food manufacture [31]. The nutritive sweeteners currently approved by the FDA include mannitol, xylitol, sorbitol and erythritol [32]. The European Food Safety Authority (EFSA) has approved the non-nutritive sweeteners Acesulfame- $K$, aspartame, cyclamate, neohesperidin dihydrochalcone, saccharin, sucralose, neotame, thaumatin and stevioside, while approved nutritive sweeteners include erythritol, isomalt, lactitol, maltitol, mannitol, sorbitol and xylitol [31].

There have been a number of short-term studies evaluating the physiological responses to nutritive and non-nutritive sweeteners that have included assessment of BP. With the increasing widespread use of non-nutritive sweeteners and the documented severe clinical sequelae of $\mathrm{PPH}$, it is clearly important to ascertain the extent to which these agents decrease postprandial BP. To date, a published systematic summary of the impact of nutritive and non-nutritive sweeteners on postprandial BP has not been performed. For this systematic review, we aim to establish current scientific evidence of the effects of some of the most commonly used FDA-regulated nutritive and non-nutritive sweeteners on postprandial BP, as well as their potential applications in the management of PPH.

\section{Approach}

Based on the pathophysiology of PPH, a systematic review of the PubMed database was conducted up to March 2019 to identify articles related to the effects of different types of sweeteners on postprandial BP. The following keywords were used: "sweeteners" or "nutritive sweeteners" or "caloric sweeteners" or "sucrose" or "fructose" or "glucose" or "xylose" or "xylitol" or "erythritol" or "maltose" or "maltodextrin" or "tagatose" or "non-nutritive sweeteners" or "non-caloric sweeteners" or "sucralose" or "Acesulfame-K" or "aspartame" or "saccharin" or "stevia" or "steviol glycoside" or "neotame" or "advantame") and ("postprandial blood pressure" or "postprandial hypotension" or "hypotensive response").

Screening of studies was performed initially by assessment of the relevance of the abstract by two independent reviewers. The reference lists of relevant articles were also reviewed. Study inclusion was based on the guidelines for preferred reporting items for systematic reviews and meta-analyses (PRISMA) [33].

\section{Results}

A total of 150 papers were identified from the database search. There were no duplicate papers. Of the 150 papers, papers without full text $(n=2)$, irrelevant papers $(n=55)$, animal studies $(n=12)$, reviews $(n=9)$, papers that were unavailable in the English language $(n=7)$, letters to the editor or comments $(n=1)$, and case reports $(n=2)$ were removed, leaving a total of 62 papers which were reviewed. Figure 2 summarizes the selection process. 


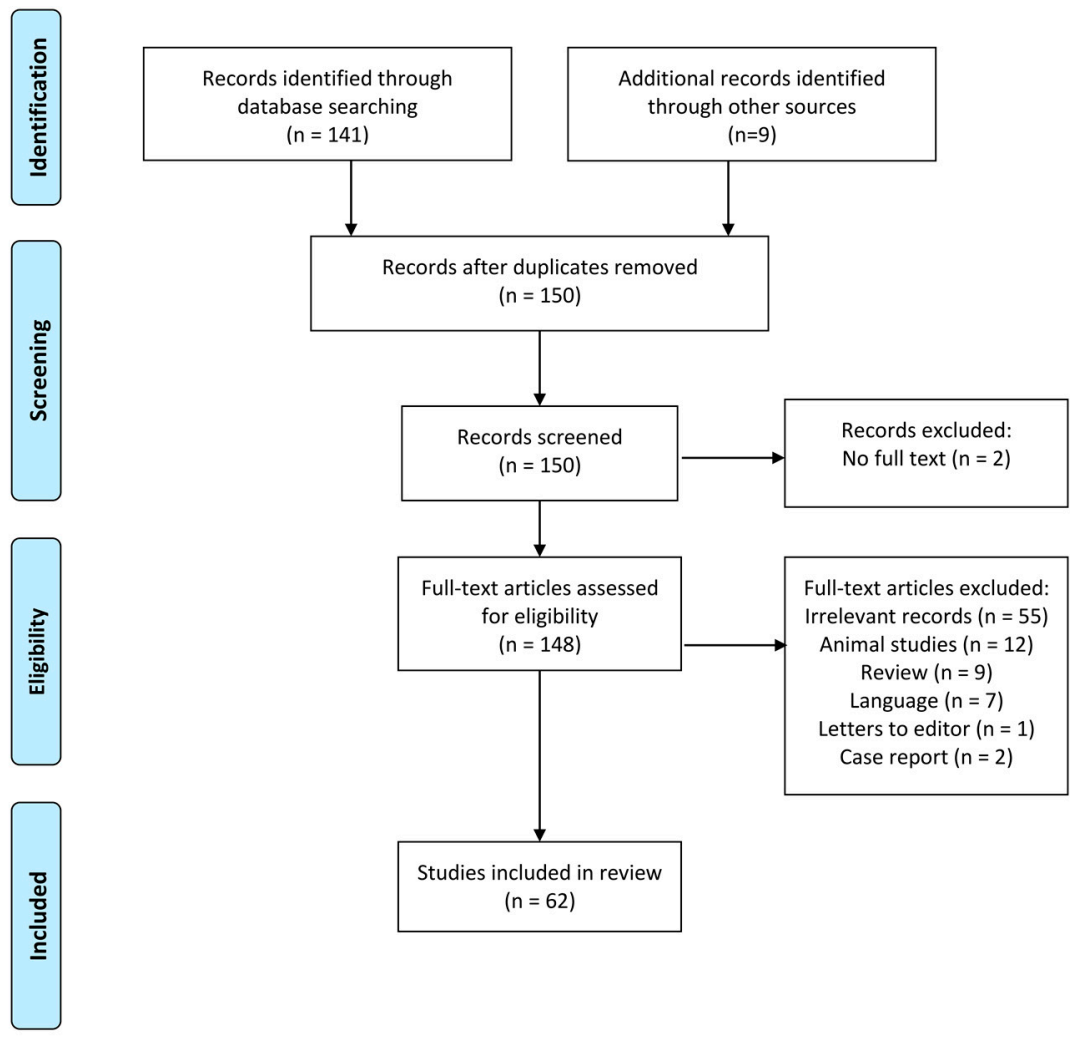

Figure 2. Flow diagram for the selection of studies for review based on the preferred reporting items for systematic reviews and meta-analyses (PRISMA) 2009 statement.

\section{Nutritive Sweeteners}

\subsection{Glucose}

Glucose is the most abundant monosaccharide and is synthesised from water and carbon dioxide through photosynthesis and concentrated to create starch [34]. Foods containing relatively higher proportions of naturally occurring glucose include some fruits, such as grapes and bananas ( 6-8\%), while the glucose content of honey may approach $\sim 38 \%$ [35,36]. It is an essential energy source for the red blood cells and brain, although the latter can also utilise ketone bodies [2,37]. Ingested complex carbohydrates are hydrolysed to monosaccharides before being absorbed [37]. The majority of studies investigating PPH have utilised an oral [11-13,16,38-73], and/or ID glucose [14,18,74-88] load that induces a substantial fall in BP. There have been a total of 58 studies related to effects of glucose on postprandial BP in a range of cohorts including health $[11,12,14,16,18,39-43,46,48-52$, 54-56,58,60,62-66,68-71,74,75,77-84,86,87,89], PPH [48,81], diabetes [11,13,16,38,57,64,67-69,76,85,88], autonomic failure [43,45,56-58], PD [47,57,71,72], hypertension [53,59-62,66], multiple system atrophy (MSA) [56-58,70] and other conditions $[41,44,45,53,65,80]$ (Table 1). Intensive care unit (ICU) survivors are more predisposed to $\mathrm{PPH}$; a marked and prolonged decrease in SBP and diastolic BP (DBP) was observed in 35 older patients discharged from the ICU [44], 10 of whom experienced PPH [44]. In healthy older participants $[11,12,46]$ and patients with T2DM [11,64], the fall in BP following glucose ingestion has been shown to be related to the rate of gastric emptying of glucose, i.e., faster gastric emptying is associated with a greater fall in BP. In contrast, in healthy young participants, there is little fall, and in some cases an increase in, SBP following oral glucose $[53,89]$. The fall in postprandial BP appears to be on a continuum so that with increasing age, the fall in BP is greater. In a study by our group, following a $75 \mathrm{~g}$ glucose drink in $300 \mathrm{~mL}$ water, there was a fall in SBP and a rise in HR in both healthy older participants and people with PPH compared with iso-volaemic water [48], however, the maximum postprandial fall in SBP was greater in the participants with PPH [48]. 
Table 1. Studies relating to the effects of glucose on blood pressure.

\begin{tabular}{|c|c|c|c|c|c|}
\hline Study & Year & Participant Characteristics & Study Design & Test Meal & Effects on Blood Pressure \\
\hline Borg et al. [38] & 2019 & $\begin{array}{l}10 \text { diet controlled T2DM patients, } \\
5 \mathrm{M}: 5 \mathrm{~F} \text {, aged } 65.6 \pm 3.1 \text { years }\end{array}$ & Randomized crossover study & $\begin{array}{l}\text { ID metformin }(1 \mathrm{~g}) \text { or saline (control) } \\
60 \mathrm{~min} \text { before ingesting a } 50 \mathrm{~g} \text { glucose } \\
\text { drink labelled with } 150 \mathrm{mg} 13 \mathrm{C} \text {-acetate. }\end{array}$ & $\begin{array}{l}\text { SBP and DBP decreased following oral glucose on } \\
\text { both days. The fall in SBP was less after } \\
\text { metformin than control. }\end{array}$ \\
\hline Brown et al. [39] & 2008 & $\begin{array}{c}15 \text { healthy normal-weight participants, } \\
9 \mathrm{M}: 6 \mathrm{~F} \text {, aged } 24 \pm 1 \text { years }\end{array}$ & Randomized crossover study & $\begin{array}{l}500 \mathrm{~mL} \text { of either water, } 60 \mathrm{~g} \text { glucose, or } \\
60 \mathrm{~g} \text { fructose. }\end{array}$ & $\begin{array}{l}\text { Oral fructose, but not glucose, significantly } \\
\text { increased SBP and DBP. The maximum rise in SBP } \\
\text { after fructose was } 6.2 \pm 0.8 \mathrm{mmHg} \text {. }\end{array}$ \\
\hline Charriere et al. [89] & 2017 & 9 young healthy men, aged $24 \pm 1$ years & Randomized crossover study & $\begin{array}{l}500 \mathrm{~mL} \text { of water containing } 60 \mathrm{~g} \text { of } \\
\text { either glucose, fructose or galactose. }\end{array}$ & $\begin{array}{l}\text { The increase in SBP after fructose }(7-8 \mathrm{mmHg}) \\
\text { was greater than after glucose }(4-5 \mathrm{mmHg}) \text { or } \\
\text { galactose }(2-3 \mathrm{mmHg}) \text {. DBP increased to a greater } \\
\text { extent with fructose }(\sim 5 \mathrm{mmHg}) \text {, compared to } \\
\text { non-significant increases of only } 2-3 \mathrm{mmHg} \text { after } \\
\text { glucose or galactose. }\end{array}$ \\
\hline Edwards et al. [51] & 1996 & $\begin{array}{c}10 \text { young ( } 20-40 \text { years), } 9 \text { middle-aged } \\
\text { (41-50 years), and } 10 \text { old (61-83 years) } \\
\text { participants }\end{array}$ & Non-randomized study & $75 \mathrm{~g}$ glucose in $300 \mathrm{~mL}$ water & $\begin{array}{l}\text { SBP decrease was significant in both the older } \\
\text { groups. A fall in SBP }>15 \mathrm{mmHg} \text { observed in } 5 \\
\text { individuals; } 4 \text { aged }>60 \text { years and } 1 \text { middle aged. }\end{array}$ \\
\hline Fagius et al. [52] & 1994 & $\begin{array}{c}39 \text { participants in } 5 \text { groups: glucose }(n \\
=8,4 \mathrm{M}: 4 \mathrm{~F}, \text { mean age } 25.8 \text { years), fat }(n \\
=8,5 \mathrm{M}: 3 \mathrm{~F} \text {, mean age } 25.5 \text { years), } \\
\text { protein ( } n=8,5 \mathrm{M}: 3 \mathrm{~F} \text {, mean age } 25.6 \\
\text { years), mixed meal ( } n=8,6 \mathrm{M}: 2 \mathrm{~F} \text {, mean } \\
\text { age } 26.2 \text { years) or water }(n=7,4 \mathrm{M}: 3 \mathrm{~F}, \\
\text { mean age } 24.9 \text { years). }\end{array}$ & Parallel study & $\begin{array}{c}100 \mathrm{~g} \text { glucose in } 300 \mathrm{~mL} \text { of water }(n= \\
8), 50 \mathrm{~g} \text { fat in } 250 \mathrm{~mL} \text { of water }(n=8), \\
100 \mathrm{~g} \text { lean meat }(40 \mathrm{~g} \text { protein) with } 250 \\
\mathrm{mL} \text { water }(n=8), 300 \mathrm{~mL} \text { water alone } \\
(n=7) \text { or a mixed meal }(n=8) .\end{array}$ & $\begin{array}{l}\text { Small and sometimes significant increases in BP } \\
\text { occurred during the sessions. }\end{array}$ \\
\hline Fagius et al. [53] & 1996 & $\begin{array}{l}3 \text { groups-A: } 9 \text { young healthy, } 5 \mathrm{M}: 4 \mathrm{~F} \text {, } \\
\text { aged } 26.2 \pm 2.8 \text { years; } \mathrm{B}: 9 \text { older healthy, } \\
\text { all } \mathrm{M}, \text { aged } 73.0 \pm 0.7 \text { years; } \mathrm{C}: 9 \mathrm{M} \text { with } \\
\text { insulin resistance aged } 72.8 \pm 1.6 \text { years }\end{array}$ & Non-randomized study & $100 \mathrm{~g}$ D-glucose in $300 \mathrm{~mL}$ & $\begin{array}{l}\text { Significant fall in BP observed in groups B and } C \\
\text { but not in group A, who demonstrated an increase } \\
\text { in SBP. }\end{array}$ \\
\hline Gentilcore et al. [74] & 2006 & $\begin{array}{c}8 \text { healthy older participants, 3M;5F, } \\
\text { aged } 65-78 \text { years }\end{array}$ & Randomized crossover study & $\begin{array}{c}50 \mathrm{~g} \text { glucose in either } 300 \mathrm{~mL}(16.7 \%) \\
600 \mathrm{~mL}(8.3 \%), \text { or } 1200 \mathrm{~mL}(4.1 \%) \text { or } \\
\text { saline }(0.9 \%) \text { at a similar rate of } 3 \\
\mathrm{kcal} / \mathrm{min}\end{array}$ & $\begin{array}{l}\text { SBP and DBP decreased, and HR increased, on all } \\
\text { days following the glucose infusions with no } \\
\text { difference between them. }\end{array}$ \\
\hline Gentilcore et al. [83] & 2007 & $\begin{array}{l}10 \text { healthy older participants, } 5 \mathrm{M}: 5 \mathrm{~F}, \\
\text { aged } 65-76 \text { years }\end{array}$ & Randomized crossover study & $\begin{array}{l}\text { Granisetron }(10 \mathrm{mcg} / \mathrm{kg}) \text { or control } \\
\text { (saline) at } t=-25 \mathrm{~min} \text {; ID glucose } \\
\text { infusion }(3 \mathrm{kcal} / \mathrm{min}) \text { for } 60 \mathrm{~min}, \\
\text { followed by ID saline for a further } 60 \\
\text { min. }\end{array}$ & $\begin{array}{l}\text { There were falls in SBP and DBP and a rise in } \mathrm{HR} \\
\text { during ID glucose; granisetron had no effect on } \\
\text { these responses. }\end{array}$ \\
\hline Gentilcore et al. [14] & 2008 & $\begin{array}{c}8 \text { healthy older participants, } 4 \mathrm{M}: 4 \mathrm{~F}, \\
\text { aged } 68-79 \text { years }\end{array}$ & Randomized crossover study & $\begin{array}{l}\text { ID glucose }(64 \mathrm{~g}) \text {, fat }(10 \% \text { oil } \\
\text { emulsion), protein }(72 \mathrm{~g} \text { whey), or } \\
\text { saline }(0.9 \%) \text { infusion at a rate of } 2.7 \\
\mathrm{~mL} / \mathrm{min} \text { for } 90 \mathrm{~min}, \text { followed by ID } \\
\text { saline for } 30 \mathrm{~min}\end{array}$ & $\begin{array}{l}\text { The maximum falls in SBP during the glucose } \\
(11.7 \pm 2.8 \mathrm{mmHg}), \text { fat }(11.7 \pm 4.8 \mathrm{mmHg}) \text {, and } \\
\text { protein }(11.0 \pm 1.5 \mathrm{mmHg} \text { ) infusion did not differ } \\
\text { significantly. The fall occurred significantly earlier } \\
\text { during the glucose ( } 18 \pm 3 \mathrm{~min}) \text { than during the fat } \\
\text { ( } 46 \pm 11 \mathrm{~min}) \text { and protein }(33 \pm 7 \mathrm{~min}) \text { infusion. }\end{array}$ \\
\hline
\end{tabular}


Table 1. Cont.

\begin{tabular}{|c|c|c|c|c|c|}
\hline Study & Year & Participant Characteristics & Study Design & Test Meal & Effects on Blood Pressure \\
\hline Gentilcore et al. [75] & 2008 & $\begin{array}{c}8 \text { healthy older participants, } 5 \mathrm{M}: 3 \mathrm{~F}, \\
\text { aged } 65-76 \text { years }\end{array}$ & Randomized crossover study & $\begin{array}{l}\text { (1) ID glucose }(50 \mathrm{~g}) \text { or }(2) \text { ID glucose } \\
(50 \mathrm{~g}) \text { with intragastric infusion of } 500 \\
\mathrm{~mL} \text { water or (3) ID saline }(0.9 \%) \text { with } \\
\text { intragastric infusion of } 500 \mathrm{~mL} \text { water. }\end{array}$ & $\begin{array}{l}\text { The fall in SBP and DBP greater during (1) and (2) } \\
\text { when compared with (3) and (1) compared with } \\
\text { (2). Gastric distension attenuated the fall in BP. }\end{array}$ \\
\hline Gentilcore et al. [54] & 2009 & $\begin{array}{c}8 \text { healthy participants, } 5 \mathrm{M}: 3 \mathrm{~F} \text {, aged } \\
66-75 \text { years }\end{array}$ & Randomized crossover study & $\begin{array}{l}\text { Day 1: ingestion of } 75 \mathrm{~g} \text { glucose in } 300 \\
\mathrm{~mL} \text {. Gastric emptying rate (kcal/min) } \\
\text { quantified by 3D ultrasound between } t \\
=0-120 \mathrm{~min} \text {. Day 2: ID glucose infused } \\
\text { at the same rate as day } 1 .\end{array}$ & $\begin{array}{l}\text { SBP was greater less after oral, compared with ID } \\
\text { glucose. }\end{array}$ \\
\hline Grasser et al. [40] & 2014 & $\begin{array}{l}12 \text { healthy young adults, } 7 \mathrm{M}: 5 \mathrm{~F} \text {, aged } \\
22.0 \pm 0.4 \text { years }\end{array}$ & Randomized crossover study & $\begin{array}{l}500 \mathrm{~mL} \text { drink of either } 60 \mathrm{~g} \text { sucrose, } 60 \\
\text { g glucose, } 60 \mathrm{~g} \text { fructose or } 30 \mathrm{~g} \text { fructose. }\end{array}$ & $\begin{array}{l}\text { Ingestion of fructose ( } 60 \text { or } 30 \mathrm{~g} \text { ) elevated SBP, } \\
\text { DBP and mean arterial pressure (MAP). Ingestion } \\
\text { of glucose elevated SBP. Ingestion of sucrose } \\
\text { showed no BP changes. The increases in DBP and } \\
\text { MAP were significantly higher for fructose ( } 60 \text { or } \\
30 \mathrm{~g} \text { ) than for either glucose or sucrose. The } \\
\text { increase in SBP was significantly higher for } \\
\text { fructose than for sucrose. }\end{array}$ \\
\hline Heseltine et al. [55] & 1991 & $\begin{array}{c}20 \text { older adults, } 10 \mathrm{M}: 10 \mathrm{~F} \text {, aged } 84 \pm 5 \\
\text { years }\end{array}$ & Randomized crossover study & $\begin{array}{c}400 \text { kcal glucose drink with either } \\
\text { caffeinated coffee or decaffeinated } \\
\text { coffee }\end{array}$ & $\begin{array}{l}\text { Maximal postprandial fall in sitting SBP was } \\
\text { attenuated by caffeine. Four participants } \\
\text { developed symptomatic PPH after placebo which } \\
\text { was prevented by caffeine. }\end{array}$ \\
\hline Hirayama et al. [56] & 1993 & $\begin{array}{l}10 \text { patients with MSA, } 9 \mathrm{M}: 1 \mathrm{~F} \text {, aged } 57 \\
\pm 7 \text { years, } 3 \text { patients with peripheral } \\
\text { autonomic neuropathy, } 2 \mathrm{M}, 1 \mathrm{~F}, \text { aged } \\
35-57 \text { years and } 16 \text { controls, } 14 \mathrm{M}: 2 \mathrm{~F}, \\
\text { aged } 38 \pm 11 \text { years. }\end{array}$ & Non-randomized study & $75 \mathrm{~g}$ glucose in $225 \mathrm{~mL}$ water & $\begin{array}{l}\text { In MSA, ingestion of glucose resulted in a rapid } \\
\text { and significant fall of SBP and DBP. In peripheral } \\
\text { autonomic neuropathy, BP decreased within } 15 \\
\text { min of oral glucose ingestion, but soon recovered. } \\
\text { BP in the controls remained unchanged. }\end{array}$ \\
\hline Hirayama et al. [56] & 1993 & $\begin{array}{l}5 \text { patients with MSA, 3M:2F, aged } \\
50-71 \text { years, } 2 \text { patients with pure } \\
\text { autonomic failure, 2M: } 54-78 \text { years and } \\
\text { 1 71-year-old F patient with autonomic } \\
\text { failure and Parkinson's disease. All } \\
\text { with PPH and OH }\end{array}$ & Crossover study & $\begin{array}{l}\text { Denopamine and midodrine } \\
\text { administered } 30 \text { min before } 75 \mathrm{~g} \\
\text { glucose drink on one day versus no } \\
\text { drug a few days prior. }\end{array}$ & $\begin{array}{l}\text { PPH was prevented by denopamine and } \\
\text { midodrine. }\end{array}$ \\
\hline Hoeldtke et al. [58] & 1989 & $\begin{array}{l}6 \mathrm{MSA} \text { patients, } 4 \mathrm{M}: 2 \mathrm{~F} \text {, aged } 53-73 \\
\text { years, } 5 \text { progressive autonomic failure } \\
\text { patients, 3M:2F, aged } 41-84 \text { years) and } \\
14 \text { controls, } 9 \mathrm{M}: 2 \mathrm{~F} \text {, aged } 36-89 \text { years. }\end{array}$ & Crossover study & $\begin{array}{l}\text { SMS-201-995 }(0.8 \mathrm{mcg} / \mathrm{kg}) \text { or placebo } \\
\text { injection sc before consuming a } 50 \mathrm{~g} \\
\text { glucose drink. }\end{array}$ & $\begin{array}{l}\text { In patients with progressive autonomic failure and } \\
\text { MSA, glucose ingestion caused a decrease in BP } \\
\text { which was attenuated by SMS-201-995. }\end{array}$ \\
\hline Jansen et al. [41] & 1987 & $\begin{array}{l}10 \text { young normotensive people, aged } 28 \\
\pm 1 \text { years (YN), } 10 \text { young hypertensive } \\
\text { patients, aged } 44 \pm 2 \text { years }(\mathrm{YH}), 10 \\
\text { elderly normotensive people aged } 75 \pm \\
2 \text { years (EN), } 10 \text { elderly hypertensive } \\
\text { patients aged } 75 \pm 1 \text { years }(\mathrm{EH}) .\end{array}$ & Randomized crossover study & $\begin{array}{l}300 \mathrm{~mL} \text { drink of either } 75 \mathrm{~g} \text { glucose or } \\
75 \mathrm{~g} \text { fructose. }\end{array}$ & $\begin{array}{c}\text { Glucose decreased MAP significantly in the EH, } \\
\text { EN and YH group. After fructose, BP remained } \\
\text { unchanged in } 4 \text { groups. }\end{array}$ \\
\hline
\end{tabular}


Table 1. Cont

\begin{tabular}{|c|c|c|c|c|c|}
\hline Study & Year & Participant Characteristics & Study Design & Test Meal & Effects on Blood Pressure \\
\hline Jansen et al. [59] & 1988 & $\begin{array}{l}\text { Hypertensive patients: randomised to } \\
\text { nitrendipine: } 4 \mathrm{M}: 5 \mathrm{~F} \text {, aged } 70-78 \\
\text { years—or hydrochlorothiazide: } 3 \mathrm{M}: 10 \mathrm{~F} \text {, } \\
\text { aged } 70-84 \text { years }\end{array}$ & Randomized parallel study & $\begin{array}{l}75 \mathrm{~g} \text { glucose drink before and after } \\
\text { treatment with } 20 \mathrm{mg} \text { nitrendipine once } \\
\text { daily or } 50 \mathrm{mg} \text { hydrochlorothiazide } \\
\text { once daily for } 12 \text { weeks. }\end{array}$ & $\begin{array}{l}\text { After } 12 \text { weeks of treatment, nitrendipine reduced } \\
\text { the fall in MAP after oral glucose }(6 \%, p<0.01) \\
\text { but this was not significant for } \\
\text { hydrochlorothiazide }(4 \%, N S) \text {. }\end{array}$ \\
\hline Jansen et al. [60] & 1989 & $\begin{array}{l}10 \text { hypertensive participants, } 3 \mathrm{M}: 7 \mathrm{~F} \\
\text { aged } 74 \pm 4 \text { years; and } 10 \text { normotensive } \\
\text { participants, } 4 \mathrm{M}: 6 \mathrm{~F} \text {, aged } 74 \pm 4 \text { years }\end{array}$ & Randomized crossover study & $\begin{array}{l}\text { Octreotide ( } 50 \mathrm{mcg} \text { sc) or placebo ( } 154 \\
\mathrm{mmol} / \mathrm{L} \mathrm{NaCl} \text { before oral } 75 \mathrm{~g} \text { glucose } \\
\text { in } 300 \mathrm{~mL} \text { water }\end{array}$ & $\begin{array}{l}\text { Octreotide attenuated the fall in MAP }(15 \pm 1 \\
\mathrm{mmHg} \text { in the } 10 \text { hypertensive participants and } 7 \pm \\
2 \mathrm{mmHg} \text { in the } 10 \text { normotensive participants }) \\
\text { induced by oral glucose. }\end{array}$ \\
\hline Jansen et al. [61] & 1989 & $\begin{array}{c}10 \text { hypertensive participants, } 7 \mathrm{M}: 3 \mathrm{~F} \\
\text { aged } 73 \pm 3 \text { years }\end{array}$ & Randomized crossover study & $\begin{array}{l}\text { Octreotide }(50 \mathrm{mcg} \mathrm{sc}) \text { at } t=-30 \mathrm{~min} \\
\text { followed by placebo or insulin }(0.3 \\
\mathrm{U} / \mathrm{kg} \text { ) sc at } t=-10 \mathrm{~min} \text { and oral glucose } \\
(75 \mathrm{~g} \text { in } 300 \mathrm{~mL} \text { water }) \text { at } t=0 \mathrm{~min}\end{array}$ & $\begin{array}{l}\text { The fall in MAP after oral glucose was attenuated } \\
\text { by octreotide with no difference between the } \\
\text { insulin and placebo study days. }\end{array}$ \\
\hline Jansen et al. [62] & 1989 & $\begin{array}{c}15 \text { older hypertensives }(\mathrm{EH}), 7 \mathrm{M}: 8 \mathrm{~F} \\
\text { age } 73 \pm 3 \text { years, } 15 \text { older } \\
\text { normotensives (EN), } 6 \mathrm{M}: 6 \mathrm{~F} \text {, age } 76 \pm 4 \\
\text { years and } 10 \text { young normotensives } \\
\text { (YN), } 5 \mathrm{M}: 5 \mathrm{~F} \text {, age } 26 \pm 4 \text { years. }\end{array}$ & Non-randomized study & $75 \mathrm{~g}$ glucose in $300 \mathrm{~mL}$ water & $\begin{array}{l}\text { In both elderly groups MAP decreased } \\
\text { significantly after the glucose load, whereas no } \\
\text { change was observed in the YN. Glucose load did } \\
\text { not influence baroreflex sensitivity. }\end{array}$ \\
\hline Jones et al. [11] & 1998 & $\begin{array}{l}16 \text { T2DM patients, } 11 \mathrm{M}: 5 \mathrm{~F} \text {, aged } 39-79 \\
\text { years; } 10 \text { young healthy participants, } \\
\text { 9M:9F, aged 19-26 years; } 9 \text { older } \\
\text { healthy participants, 6M:3F, aged } 40-68 \\
\text { years old. }\end{array}$ & Non-randomized study & $75 \mathrm{~g}$ glucose in $350 \mathrm{~mL}$ water & $\begin{array}{l}\text { The fall in MAP was significantly greater in the } \\
\text { T2DM than in older healthy participants with no } \\
\text { change in young healthy participants. The } \\
\text { magnitude of the fall in BP was related to the rate } \\
\text { of gastric emptying. }\end{array}$ \\
\hline Jones et al. [11] & 2005 & $\begin{array}{l}10 \text { healthy participants, } 6 \mathrm{M}: 6 \mathrm{~F} \text {, aged } \\
73.9 \pm 1.2 \text { years }\end{array}$ & Randomized crossover study & $\begin{array}{c}25 \mathrm{~g} \text { glucose in } 200 \mathrm{~mL}(12.5 \%), 75 \mathrm{~g} \\
\text { glucose in } 200 \mathrm{~mL}(37.5 \%), 25 \mathrm{~g} \text { glucose } \\
\text { in } 600 \mathrm{~mL}(4 \%) \text {, and } 75 \mathrm{~g} \text { glucose in } 600 \\
\mathrm{~mL}(12.5 \%)\end{array}$ & $\begin{array}{l}\text { Increased drink volume attenuates the fall in BP } \\
\text { with no effect of glucose concentration. }\end{array}$ \\
\hline Jones et al. [63] & 2001 & $\begin{array}{l}10 \text { healthy participants, } 5 \mathrm{M}: 5 \mathrm{~F} \text {, aged } \\
67-78 \text { years }\end{array}$ & Randomized crossover study & $\begin{array}{l}300 \mathrm{~mL} \text { water containing } 50 \mathrm{~g} \text { glucose } \\
\text { with } 30 \mathrm{~mL} \text { lemon juice made up to } 300 \\
\mathrm{~mL} \text { with or without } 9 \mathrm{~g} \text { guar gum }\end{array}$ & $\begin{array}{l}\text { SBP, DBP and MAP fell on both days. The } \\
\text { magnitude of the falls in SBP, DBP, and MAP were } \\
\text { less, after guar. }\end{array}$ \\
\hline Jones et al. [64] & 2019 & $\begin{array}{c}15 \text { healthy participants, } 9 \mathrm{M}: 6 \mathrm{~F} \text {, aged } \\
67.2 \pm 2.3 \text { years and } 15 \mathrm{~T} 2 \mathrm{DM} \text { patients, } \\
9 \mathrm{M}: 6 \mathrm{~F} \text {, aged } 61.9 \pm 2.3 \text { years })\end{array}$ & Randomized crossover study & $\begin{array}{c}\text { Lixisenatide }(10 \mathrm{mcg}) \text { or placebo sc } \\
30 \text { min before } 75 \mathrm{~g} \text { glucose drink on } \\
\text { two separate days. }\end{array}$ & $\begin{array}{l}\text { Lixisenatide attenuated the decrease in SBP and } \\
\text { DBP compared to placebo in healthy participants } \\
\text { and those with T2DM }\end{array}$ \\
\hline Marathe et al. [76] & 2016 & $\begin{array}{l}9 \text { patients with T2DM, all M, aged } 62 \pm \\
2.4 \text { years }\end{array}$ & Randomized crossover study & $\begin{array}{l}\text { ID glucose }(25 \mathrm{~g} / 100 \mathrm{~mL}) \text { infused at } 2 \\
\mathrm{kcal} / \mathrm{min} \text { or } 4 \mathrm{kcal} / \mathrm{min}\end{array}$ & $\begin{array}{l}\text { SBP and DBP fell at } 30 \mathrm{~min} \text { with } 4 \mathrm{kcal} / \mathrm{min} \text {, but } \\
\text { not } 2 \mathrm{kcal} / \mathrm{min} \text { infusions. The fall in SBP was } \\
\text { greater after the } 4 \mathrm{kcal} / \mathrm{min} \text { infusion. }\end{array}$ \\
\hline
\end{tabular}


Table 1. Cont

\begin{tabular}{|c|c|c|c|c|c|}
\hline Study & Year & Participant Characteristics & Study Design & Test Meal & Effects on Blood Pressure \\
\hline Maruta et al. [76] & 2006 & $\begin{array}{l}28 \text { neurologic patients ( } 11 \text { with PD, } \\
\text { 4M:7F, aged 61-86 years; } 6 \text { with MSA, } \\
\text { 4M:2F, aged 53-76 years; } 11 \text { with } \\
\text { T2DM, 8M:3F, aged } 62-85 \text { years) and } 20 \\
\text { healthy controls ( } 13 \text { older participants, } \\
\text { 5M:8F, aged } 62-80 \text { years; } 7 \text { young } \\
\text { participants, 4M:3F, aged } 34-59 \text { years). }\end{array}$ & Crossover study & $\begin{array}{l}75 \mathrm{~g} \text { glucose with or without } 200 \mathrm{mcg} \\
\text { voglibose. All participants were } \\
\text { studied on the day without voglibose. } \\
11 \text { of them ( } 4 \text { with PD, } 5 \text { with MSA, } 1 \\
\text { with T2DM, } 1 \text { older control), who had } \\
\text { PPH, were studied on the day with } \\
\text { voglibose. }\end{array}$ & $\begin{array}{l}\text { The fall in BP was less (without voglibose: } 41.5 \pm \\
13.2 \mathrm{mmHg} \text {, with voglibose: } 21.0 \pm 13.0 \mathrm{mmH} \text { ) } \\
\text { and the duration of PPH was shorter (without } \\
\text { voglibose: } 52.3 \pm 28.0 \mathrm{~min} \text {, with voglibose: } 17.3 \pm \\
22.5 \mathrm{~min} \text { ) after voglibose. }\end{array}$ \\
\hline Masuo et al. [66] & 1996 & $\begin{array}{c}12 \text { young normotensive }(\mathrm{NT}) \\
\text { participants, aged } 47.8 \pm 2.6 \text { years; } 21 \\
\text { elderly NT, aged } 77.9 \pm 1.5 \text { years; } 17 \\
\text { young hypertensive }(\mathrm{EH}) \text { patients, } \\
\text { aged } 49.0 \pm 1.9 \text { years and } 32 \text { elderly EH. } \\
1 \mathrm{M}: 1 \mathrm{~F} \text { in each group. }\end{array}$ & Non-randomized study & $75 \mathrm{~g}$ glucose in $225 \mathrm{~mL}$ water & $\begin{array}{l}\text { Postprandial BP reduction, defined as 10\% or } \\
\text { more decline in MAP was recognized in 3/12 (25\%) } \\
\text { young NT, } 9 / 21(43 \%) \text { elderly NT, 5/17 ( } 29 \%) \text { young } \\
\text { EH, and 20/32 (63\%) elderly EH. The frequency of } \\
\text { postprandial BP reduction was significantly } \\
\text { greater in elderly hypertensives compared to } \\
\text { elderly normotensives and was greater in young } \\
\text { hypertensives compared to young normotensives. }\end{array}$ \\
\hline Mathias et al. [43] & 1989 & $\begin{array}{l}6 \text { patients with chronic autonomic } \\
\text { failure (CAF), } 4 \mathrm{M}: 2 \mathrm{~F} \text {, aged } 42-68 \text { years, } \\
6 \text { age-matched participants without } \\
\text { CAF, aged } 45-70 \text { years; and } 8 \text { normal } \\
\text { participants, all M, aged } 28-35 \text { years. }\end{array}$ & Randomized parallel study & $\begin{array}{l}\text { An iso-osmotic solution of glucose }(1 \\
\mathrm{g} / \mathrm{kg} \text { body weight) or xylose }(0.83 \mathrm{~g} / \mathrm{kg} \\
\text { body weight) in } 250 \mathrm{~mL} \text { water. } 6 \\
\text { patients with CAF attended } 2 \text { on both } \\
\text { glucose and xylose days. } 6 \\
\text { age-matched participants and } 8 \text { male } \\
\text { normal participants attended only on } \\
\text { the glucose day. }\end{array}$ & $\begin{array}{c}\text { Xylose caused a lower and more transient fall in } \\
\text { BP than glucose in patients with CAF ( } 15 \pm 6 \% \text { vs } \\
34 \pm 7 \% \text { ). After glucose, there was a substantial } \\
\text { fall in } 6 \text { age-matched participants but a minimal } \\
\text { change in } 8 \text { male normal participants. }\end{array}$ \\
\hline Nair et al. [67] & 2015 & $\begin{array}{l}13 \text { participants with } \mathrm{PPH}, 4 \mathrm{M}: 9 \mathrm{~F} \text {, aged } \\
76.5 \pm 4 \text { years. }\end{array}$ & Randomized crossover study & $\begin{array}{l}\text { Ingestion of } 50 \mathrm{~g} \text { glucose in } 200 \mathrm{~mL} \text { on } \\
\text { both days. On one day, participants } \\
\text { walked at their usual pace for } 30 \mathrm{~m} \\
\text { every } 30 \text { min for } 120 \mathrm{~min} .\end{array}$ & $\begin{array}{l}\text { On the control day, there were significant falls in } \\
\text { SBP and DBP. On the intervention day, there was } \\
\text { no significant fall in SBP, however, DBP still fell } \\
\text { significantly. }\end{array}$ \\
\hline Nair et al. [68] & 2016 & $\begin{array}{l}29 \text { older participants, } 18 \mathrm{~F} \text { aged } 77.1 \pm \\
5.4 \text { years and } 11 \mathrm{M} \text { aged } 74.7 \pm 3.9 \text { years }\end{array}$ & Randomized crossover study & $\begin{array}{c}3 \text { treatments: glucose }(50 \mathrm{~g} \text { in } 200 \mathrm{~mL}) \\
(\mathrm{G}) \text { or water }(200 \mathrm{~mL}) \text { and intermittent } \\
\text { walking (WW) or glucose and walking } \\
(\mathrm{GW})\end{array}$ & $\begin{array}{l}16 \text { participants had PPH. In PPH, there was a } \\
\text { significant fall in SBP ( } 26.69 \pm 8.43 \mathrm{mmHg} \text { ) on the } \\
\text { "G" day and no change on "GW" or "WW" days. } \\
\text { In those without PPH, there were no changes in } \\
\text { SBP on the "G" or "GW" days, with an increase in } \\
\text { SBP on the "WW" day. }\end{array}$ \\
\hline Nguyen et al. [44] & 2018 & $\begin{array}{l}35 \text { older participants, } 28 \mathrm{M}: 7 \mathrm{~F} \text {, aged } 73 \\
\pm 5 \text { years, discharged at least } 3 \text { months } \\
\text { from ICU }\end{array}$ & Non-randomized study & $300 \mathrm{~mL}$ drink containing $75 \mathrm{~g}$ glucose & $\begin{array}{l}\text { There were significant reductions in both SBP and } \\
\text { DBP. Ten participants }(29 \%) \text { had postprandial } \\
\text { hypotension. The maximal fall in SBP and DBP } \\
\text { were }-29 \pm 14 \mathrm{mmHg} \text { and }-18 \pm 7 \mathrm{mmHg} \text {. The } \\
\text { maximal fall in SBP was greater in patients with } \\
\text { PPH than in those without }(-46.2 \pm 10.8 \mathrm{mmHg} \text { vs. } \\
-22.7 \pm 9.2 \mathrm{mmHg}) .\end{array}$ \\
\hline
\end{tabular}


Table 1. Cont

\begin{tabular}{|c|c|c|c|c|c|}
\hline Study & Year & Participant Characteristics & Study Design & Test Meal & Effects on Blood Pressure \\
\hline O'Donovan et al. [77] & 2002 & $\begin{array}{c}8 \text { healthy elderly participants, } 4 \mathrm{M}: 4 \mathrm{~F} \\
\text { aged } 70.3 \pm 3.4 \text { years }\end{array}$ & Randomized crossover study & $\begin{array}{c}25 \% \text { glucose solution was infused } \\
\text { intraduodenally at a rate of either } 1 \text { or } \\
3 \mathrm{kcal} / \mathrm{min} \text { for } 60 \text { min followed by } 0.9 \% \\
\text { saline for a further } 60 \mathrm{~min}\end{array}$ & $\begin{array}{l}\text { Between } \mathrm{t}=0-60 \mathrm{~min} \text {, there was a fall in SBP, DBP } \\
\text { and MAP during the } 3 \mathrm{kcal} / \mathrm{min} \text { glucose infusion, } \\
\text { but not during the } 1 \mathrm{kcal} / \mathrm{min} \text { infusion. }\end{array}$ \\
\hline O'Donovan et al. [84] & 2005 & $\begin{array}{l}8 \text { healthy older participants, } 4 \mathrm{M}: 4 \mathrm{~F}, \\
\text { aged } 70.3 \pm 3.4 \text { years }\end{array}$ & Randomized crossover study & $\begin{array}{l}\text { ID glucose infusion }(3 \mathrm{kcal} / \mathrm{min} \text { ) with } \\
\text { or without guar gum }(4 \mathrm{~g}) \text { for } 60 \mathrm{~min} \text {, } \\
\text { followed by } 0.9 \% \text { saline } \\
\text { intraduodenally for a further } 60 \mathrm{~min} \text {. }\end{array}$ & $\begin{array}{l}\text { Between } \mathrm{t}=0-60 \mathrm{~min}, \mathrm{SBP} \text { was lower during the } \\
\text { glucose-only infusion than during the glucose and } \\
\text { guar infusion. The maximum fall in SBP on the } \\
\text { glucose-only study was } 10 \pm 4 \mathrm{mmHg} \text {. Between } t \\
=0-30 \mathrm{~min}, \mathrm{DBP} \text { fell during the glucose-only } \\
\text { infusion, but did not change with the glucose and } \\
\text { guar infusion. }\end{array}$ \\
\hline Pham et al. [78] & 2018 & $\begin{array}{l}12 \text { healthy participants, } 6 \mathrm{M}: 6 \mathrm{~F} \text {, aged } \\
73.2 \pm 1.1 \text { years }\end{array}$ & Randomized crossover study & $\begin{array}{l}\text { ID infusion of either glucose }(25 \%, \\
\sim 1400 \mathrm{mOsmol} / \mathrm{L}) \text {, sucralose }(4 \mathrm{mmol} / \mathrm{L}, \\
\sim 300 \mathrm{mOsmol} / \mathrm{L}) \text { or saline }(0.9 \%, \sim 300 \\
\mathrm{mOsmol} / \mathrm{L}) \text { at a rate of } 3 \mathrm{~mL} / \mathrm{min} \text { for } 60 \\
\text { min followed by ID saline for a further } \\
60 \text { min. }\end{array}$ & $\begin{array}{c}\text { MAP decreased during glucose but not during } \\
\text { sucralose or saline. By } t=60 \mathrm{~min}, \mathrm{MAP} \text { was lower } \\
\text { after glucose }(85.9 \pm 2.8 \mathrm{mmHg}) \text { than after } \\
\text { sucralose }(93.1 \pm 2.2 \mathrm{mmHg}) \text { infusions without } \\
\text { significant difference between sucralose and saline } \\
\text { infusions. }\end{array}$ \\
\hline Pham et al. [12] & 2019 & $\begin{array}{c}33 \text { healthy older participants, } 16 \mathrm{M}: 17 \mathrm{~F}, \\
\text { aged } 77.0 \pm 0.7 \text { years }\end{array}$ & $\begin{array}{l}\text { Non-randomized study } \\
\text { longitudinal study }\end{array}$ & $75 \mathrm{~g}$ glucose in $300 \mathrm{~mL}$ water & $\begin{array}{l}\text { The prevalence of PPH doubled from } 9.1 \% \text { to } \\
18.2 \% \text {. } \\
\text { There was a fall in SBP and DBP on both study } \\
\text { days. The AUC of SBP was greater at follow-up. } \\
\text { The maximum fall in postprandial SBP between } t \\
=60-120 \text { min was significantly greater at } \\
\text { follow-up (-11.7 } \pm 1.4 \text { vs. }-15.2 \pm 1.6 \mathrm{mmHg}) \text {. }\end{array}$ \\
\hline Robinson et al. [45] & 1992 & $\begin{array}{l}5 \text { participants with age-related } \mathrm{OH}, \\
\text { 2M:3F, aged } 73-88 \text { years), } 3 \\
\text { participants with autonomic failure, } \\
\text { 1M:2F, aged } 72-79 \text { years and } 5 \text { controls, } \\
\text { 2M:3F, aged } 72-86 \text { years }\end{array}$ & Randomized crossover study & $\begin{array}{c}50 \mathrm{~g} \text { glucose or } 42 \mathrm{~g} \text { xylose in } 100 \mathrm{~mL} \\
\text { water }\end{array}$ & $\begin{array}{l}\text { In OH and autonomic failure groups, the SBP } \\
\text { decreased comparably following glucose and } \\
\text { xylose, DBP was lowered } 60-90 \text { min after glucose. } \\
\text { No significant BP changes in the control group. }\end{array}$ \\
\hline Russo et al. [13] & 2003 & $\begin{array}{l}11 \text { patients with T2DM managed by } \\
\text { diet alone, } 8 \mathrm{M}: 3 \mathrm{~F} \text {, aged } 61.9 \pm 1.3 \text { years }\end{array}$ & Randomized crossover study & $\begin{array}{c}50 \mathrm{~g} \text { glucose and } 30 \mathrm{~mL} \text { lemon juice, } \\
\text { with or without } 9 \mathrm{~g} \text { guar gum in } 300 \\
\mathrm{~mL} \text {. }\end{array}$ & $\begin{array}{l}\text { There was significant fall in SBP between baseline } \\
\text { and } 30 \mathrm{~min} \text { on the control day }(143.9 \pm 4.7 \mathrm{mmHg} \\
\text { vs. } 139.0 \pm 4.2 \mathrm{mmHg} ; p<0.01), \text { but not after guar } \\
\text { (145.1 } \pm 4.8 \mathrm{mmHg} \text { vs. } 142.6 \pm 4.5 \mathrm{mmHg}, p=0.6) \text {. } \\
\text { There were significant falls in DBP and MAP } \\
\text { between baseline and } 30 \text { min on both study days. }\end{array}$ \\
\hline Sasaki et al. [69] & 1992 & $\begin{array}{l}15 \text { normal participants, aged } 25-63 \\
\text { years and } 35 \text { outpatients with T2DM, } \\
\text { aged } 28-60 \text { years }\end{array}$ & Non-randomized study & $\begin{array}{c}\text { Daily meals and } 75 \mathrm{~g} \text { glucose in } 300 \mathrm{~mL} \\
\text { water }\end{array}$ & $\begin{array}{l}\text { No significant change in BP in the normal } \\
\text { participants. } \\
\text { The incidence of PPH in diabetics was 37\% after } \\
\text { daily meal and } 20 \% \text { after } 75 \text { g glucose. }\end{array}$ \\
\hline Takamori et al. [70] & 2007 & $\begin{array}{c}17 \text { MSA patients, } 9 \mathrm{M}: 8 \mathrm{~F} \text {, aged } 59.8 \pm 7.9 \\
\text { years and } 8 \text { healthy controls, } 7 \mathrm{M}: 1 \mathrm{~F} \\
\text { aged } 60.5 \pm 8.3 \text { years }\end{array}$ & Non-randomized study & $75 \mathrm{~g}$ of glucose in $225 \mathrm{~mL}$ of water & $\begin{array}{l}\text { Of } 17 \text { MSA patients, } 9 \text { had PPH. } 8 \text { controls were } \\
\text { PPH negative. The falls in SBP and DBP in MSA } \\
\text { with PPH were significantly greater than in MSA } \\
\text { without PPH or in controls. }\end{array}$ \\
\hline
\end{tabular}


Table 1. Cont.

\begin{tabular}{|c|c|c|c|c|c|}
\hline Study & Year & Participant Characteristics & Study Design & Test Meal & Effects on Blood Pressure \\
\hline Thazhath et al. [85] & 2017 & $\begin{array}{l}9 \text { patients with T2DM, managed by } \\
\text { diet alone, } 6 \mathrm{M}: 3 \mathrm{~F} \text {, aged } 60.7 \pm 2.4 \text { years }\end{array}$ & Randomized crossover study & $\begin{array}{c}\text { Intravenous exenatide }(7.5 \mathrm{mcg}) \text { or } \\
\text { volume-matched saline control from } \\
-30 \text { to } 120 \mathrm{~min}+\text { ID glucose } \\
(3 \mathrm{kcal} / \mathrm{min}) \text { from } 0-60 \mathrm{~min} .\end{array}$ & $\begin{array}{l}\text { During the ID glucose infusion, SBP, DBP and } \\
\text { MAP increased with exenatide, but fell with saline } \\
\text { control. The AUC for DBP and MAP, but not SBP, } \\
\text { was higher with exenatide than control. }\end{array}$ \\
\hline Trahair et al. [16] & 2015 & $\begin{array}{c}14 \text { older healthy participants, } 6 \mathrm{M}: 8 \mathrm{~F}, \\
\text { aged } 72.1 \pm 1.1 \text { years and } 10 \text { patients } \\
\text { with T2DM, } 6 \mathrm{M}: 4 \mathrm{~F} \text {, aged } 68.7 \pm 3.4 \\
\text { years }\end{array}$ & Randomized crossover study & $\begin{array}{c}\text { Between } t=-30-120 \mathrm{~min}: \text { intravenous } \\
\text { infusion of GLP- } 1(0.9 \mathrm{pmol} / \mathrm{kg} / \mathrm{min}) \text { or } \\
\text { saline }(154 \mathrm{mmol} / \mathrm{l} \mathrm{NaCl}) . \\
\text { At } t=0 \text { min: } 75 \mathrm{~g} \text { glucose drink in } 300 \\
\text { mL water }\end{array}$ & $\begin{array}{l}\text { After the glucose drink there were falls in SBP and } \\
\text { DBP in both groups. } \\
\text { The fall in DBP in older individuals; and the fall in } \\
\text { SBP and DBP in patients with T2DM were less } \\
\text { after GLP-1 infusion compared to control. }\end{array}$ \\
\hline Trahair et al. [79] & 2012 & $\begin{array}{c}12 \text { healthy young participants, } 6 \mathrm{M} ; 6 \mathrm{~F}, \\
\text { aged } 22.2 \pm 2.3 \text { years and } 12 \text { healthy } \\
\text { older participants, } 6 \mathrm{M} ; 6 \mathrm{~F} \text {, aged } 68.7 \pm \\
1.0 \text { years }\end{array}$ & Randomized crossover study & $\begin{array}{l}\text { ID infusion of glucose at either } 1,2 \text { or } 3 \\
\mathrm{kcal} / \mathrm{min} \text { or } 0.9 \% \text { normal saline for } 60 \\
\mathrm{~min} \text { followed by ID saline for a further } \\
60 \mathrm{~min} .\end{array}$ & $\begin{array}{l}\text { In young participants, there were no changes in } \\
\text { SBP and DBP during the four infusions. In older } \\
\text { participants, there were falls in SBP and DBP } \\
\text { during } 2 \mathrm{kcal} / \mathrm{min} \text { and } 3 \mathrm{kcal} / \mathrm{min} \text { infusions, but } \\
\text { not during } 1 \mathrm{kcal} / \mathrm{min} \text { infusion. }\end{array}$ \\
\hline Trahair et al. [18] & 2014 & $\begin{array}{l}10 \text { healthy older participants, } 9 \mathrm{M}: 1 \mathrm{~F} \\
\text { aged } 73.2 \pm 1.5 \text { years }\end{array}$ & Randomized crossover study & $\begin{array}{l}\text { Between } t=-30-60 \mathrm{~min} \text {, intravenous } \\
\text { infusion of GLP- } 1(0.9 \mathrm{pmol} / \mathrm{kg} / \mathrm{min}) \text {, or } \\
\text { saline for } 90 . \text { Between } t=0-60 \mathrm{~min} \text {, ID } \\
\text { glucose was infused at } 3 \mathrm{kcal} / \mathrm{min} \text {. }\end{array}$ & $\begin{array}{l}\text { During ID glucose infusion, there were falls in SBP } \\
\text { and DBP with both GLP- } 1 \text { and control. The } \\
\text { maximum fall in SBP was greater with control than } \\
\text { GLP-1 ( }-13.6 \pm 3.1 \mathrm{mmHg} \text { vs. }-8.7 \pm 2.3 \mathrm{mmH}) \text {. }\end{array}$ \\
\hline Trahair et al. [46] & 2015 & $\begin{array}{l}88 \text { healthy older participants, } 41 \mathrm{M}: 47 \mathrm{~F}, \\
\text { aged } 71.0 \pm 0.5 \text { years }\end{array}$ & Non-randomized study & $75 \mathrm{~g}$ glucose in $300 \mathrm{~mL}$ water & $\begin{array}{l}\text { SBP and DBP decreased significantly after the } \\
\text { glucose drink. Eleven participants }(12.8 \%) \text { had } \\
\text { PPH. }\end{array}$ \\
\hline Trahair et al. [47] & 2016 & $\begin{array}{l}21 \text { participants with mild to moderate } \\
\text { PD, } 13 \mathrm{M}: 8 \mathrm{~F} \text {, aged } 64.2 \pm 1.6 \text { years }\end{array}$ & Crossover study & $75 \mathrm{~g}$ glucose in $300 \mathrm{~mL}$ water & $\begin{array}{l}\text { SBP and DBP fell following the glucose drink. } 8 \\
\text { participants }(38 \%) \text { had postprandial hypotension. }\end{array}$ \\
\hline Trahair et al. [48] & 2017 & $\begin{array}{l}8 \text { healthy older participants, } 4 \mathrm{M}: 4 \mathrm{~F}, \\
\text { aged } 71.0 \pm 1.7 \text { years and } 8 \text { participants } \\
\text { with PPH } 1 \mathrm{M}: 7 \mathrm{~F} \text {, aged } 75.5 \pm 1.0 \text { years }\end{array}$ & Randomized crossover study & $\begin{array}{c}75 \mathrm{~g} \text { glucose in } 300 \mathrm{~mL} \text { water or water } \\
\text { alone }\end{array}$ & $\begin{array}{l}\text { Following the glucose, there were decreases in } \\
\text { SBP and DBP in both groups, the maximum fall in } \\
\text { SBP was greater in participants with PPH. } \\
\text { Following the water, there were no changes in SBP } \\
\text { and DBP in healthy participants, but there was a } \\
\text { rise in SBP in participants with PPH. }\end{array}$ \\
\hline Trahair et al. [80] & 2018 & $\begin{array}{c}12 \text { obese participants, } 10 \mathrm{M}: 2 \mathrm{~F} \text {, aged } \\
\left.36.6 \pm 3.9 \text { years, BMI: } 36.1 \pm 1.3 \mathrm{~kg} / \mathrm{m}^{2}\right) \\
\text { and } 23 \text { controls, } 16 \mathrm{M}: 7 \mathrm{~F}, \text { aged } 27.8 \pm 2.4 \\
\text { years, BMI: } 22.4 \pm 0.5 \mathrm{~kg} / \mathrm{m}^{2}\end{array}$ & Randomized crossover study & $\begin{array}{l}\text { ID infusions of glucose at } 1 \text { or } 3 \\
\mathrm{kcal} / \mathrm{min} \text {, or } 0.9 \% \text { saline, for } 60 \mathrm{~min} \text {, } \\
\text { followed by saline for a further } 60 \mathrm{~min} \text {. }\end{array}$ & $\begin{array}{l}\text { No changes in SBP in both groups during any of } \\
\text { the conditions. There was a fall in DBP in controls } \\
\text { during } 1 \mathrm{kcal} / \mathrm{min} \text { and } 3 \mathrm{kcal} / \mathrm{min} \text { infusions; and in } \\
\text { obese participants during } 3 \mathrm{kcal} / \mathrm{min} \text { infusion. } \\
\text { There was no difference in BP responses between } \\
\text { the groups. }\end{array}$ \\
\hline Umehara et al. [71] & 2014 & $\begin{array}{c}37 \text { patients with de novo PD ( } 17 \text { with } \\
\text { PPH, } 4 \mathrm{M}: 13 \mathrm{~F} \text {, aged } 76.8 \pm 6.1 \text { years; } 20 \\
\text { without PPH, } 8 \mathrm{M}: 12 \mathrm{~F} \text {, aged } 74.4 \pm 7.5 \\
\text { years) and } 10 \text { healthy controls, aged } \\
74.3 \pm 4.8 \text { years })\end{array}$ & Non-randomized study & $75 \mathrm{~g}$ glucose in $300 \mathrm{~mL}$ water & $\begin{array}{l}\text { Of the } 37 \text { patients, } 17(45.9 \%) \text { had PPH, } 15(40.5 \%) \\
\text { had OH and } 8(21.6 \%) \text { had both PPH and OH. } \\
\text { controls had PPH. The maximum fall in SBP after } \\
\text { the glucose drink significantly correlated with that } \\
\text { on head-up tilt-table testing in PD patients. }\end{array}$ \\
\hline
\end{tabular}


Table 1. Cont.

\begin{tabular}{|c|c|c|c|c|c|}
\hline Study & Year & Participant Characteristics & Study Design & Test Meal & Effects on Blood Pressure \\
\hline Umehara et al. [72] & 2016 & $\begin{array}{c}64 \text { de novo patients with } \mathrm{PD}, 22 \mathrm{M}: 42 \mathrm{~F}, \\
\text { aged } 76 \pm 4 \text { years }\end{array}$ & Non-randomized study & $75 \mathrm{~g}$ glucose in $300 \mathrm{~mL}$ water & $\begin{array}{c}29 \text { patients had PPH. Patients with PPH } \\
\text { experienced greater reductions in SBP }(30 \pm 11 \mathrm{vs} \text {. } \\
11 \pm 15 \mathrm{mmHg}) \text { and DBP }(14 \pm 9 \mathrm{vs} .7 \pm 5 \mathrm{mmHg}) \\
\text { after glucose drink compared to patients without } \\
\text { PPH. }\end{array}$ \\
\hline van Orshoven et al. [81] & 2008 & $\begin{array}{c}8 \text { healthy young participants (4M:4F, } \\
\text { aged } 28.8 \pm 3.4 \text { years), } 8 \text { healthy elderly } \\
\text { (4M:4F, aged } 75.3 \pm 1.6 \text { years). } 2 \text { female } \\
\text { patients with symptomatic PPH aged } \\
21 \text { and } 90 \text { years }\end{array}$ & Non-randomized study & $\begin{array}{l}\text { ID infusion of } 25 \% \text { glucose at } 3 \mathrm{~mL} / \mathrm{min} \\
\text { for } 60 \text { min. Saline was infused for } 30 \\
\text { min before and after ID glucose. }\end{array}$ & $\begin{array}{l}\text { ID glucose decreased SBP, in both the young and } \\
\text { older people, but the fall in SBP was greater in the } \\
\text { older group ( }-6.5 \pm 1.6 \text { vs. }-17.0 \pm 4.1 \mathrm{mmHg}) .2 \\
\text { PPH patients had a greater fall in SBP than the } \\
\text { two healthy groups ( }-21 \text { and }-98 \mathrm{mmHg}) \text {. }\end{array}$ \\
\hline Vanis et al. [82] & 2011 & $\begin{array}{l}12 \text { healthy older participants, } 6 \mathrm{M}: 6 \mathrm{~F} \\
\text { aged } 68.7 \pm 1.0 \text { years }\end{array}$ & Randomized crossover study & $\begin{array}{c}\text { ID infusion of glucose at either } 1,2 \text { or } 3 \\
\mathrm{kcal} / \mathrm{min} \text { or } 0.9 \% \text { normal saline for } 60 \\
\mathrm{~min} \text {, followed by saline for a further } 60 \\
\text { min. }\end{array}$ & $\begin{array}{l}\text { There was a fall in SBP and DBP during } 2 \text { and } 3 \\
\mathrm{kcal} / \mathrm{min} \text { glucose infusions, but not during saline } \\
\text { or } 1 \mathrm{kcal} / \mathrm{min} \text { glucose infusion. There was no } \\
\text { difference in the maximum falls in SBP during } 2 \\
\mathrm{kcal} / \mathrm{min}(15 \pm 2 \mathrm{mmHg}) \text { and } 3 \mathrm{kcal} / \mathrm{min}(12 \pm 2 \\
\mathrm{mmHg}) \text { loads. }\end{array}$ \\
\hline Vanis et al. [49] & 2011 & $\begin{array}{c}8 \text { healthy older participants, } 6 \mathrm{M}: 2 \mathrm{~F}, \\
\text { aged } 65-75 \text { years }\end{array}$ & Randomized crossover study & $\begin{array}{l}300 \mathrm{~mL} \text { drink of water, } 50 \mathrm{~g} \text { glucose or } \\
50 \mathrm{~g} \text { D-xylose. }\end{array}$ & $\begin{array}{l}\text { There was a fall in SBP after glucose drink and no } \\
\text { change after xylose or water drink. }\end{array}$ \\
\hline Vanis et al. [86] & 2010 & 8 participants, $6 \mathrm{M}: 2 \mathrm{~F}$, aged $65-75$ yeas & Randomized crossover study & $\begin{array}{l}\text { The four treatments were as follows: } \\
\text { ID glucose ( } 3 \mathrm{kcal} / \mathrm{min} \text { ) + barostat } \\
\text { (distension) (GD), ID saline + barostat } \\
\text { (SD), ID glucose (G), and ID saline (S). }\end{array}$ & $\begin{array}{l}\text { SBP and DBP fell during G, but not during S or } \\
\text { GD; and increased during SD. The maximum } \\
\text { changes in SBP during G, GD, S and SD were }-14 \\
\pm 5,-3 \pm 4,+11 \pm 2 \text {, and }+15 \pm 3 \mathrm{mmHg} \\
\text { respectively. }\end{array}$ \\
\hline Vanis et al. [87] & 2012 & 9 participants, all $\mathrm{M}$, aged $65-75$ years & Randomized crossover study & $\begin{array}{l}\text { ID glucose infusion (3 kcal/min) and } \\
\text { gastric distension at a volume of (1) } 0 \\
\mathrm{ml} \text { (V0), (2) } 100 \mathrm{~mL} \text { (V100), (3) } 300 \mathrm{~mL} \\
\text { (V300), or (4) } 500 \mathrm{~mL} \text { (V500). }\end{array}$ & $\begin{array}{l}\text { SBP and DBP fell during V0, but did not change } \\
\text { significantly during V100, V300, V500. }\end{array}$ \\
\hline Visvanathan et al. [73] & 2006 & $\begin{array}{l}12 \text { elderly participants, } 6 \mathrm{M}: 6 \mathrm{~F} \text {, aged } \\
72.2 \pm 5.7 \text { years }\end{array}$ & Randomized crossover study & $\begin{array}{c}300 \mathrm{~mL} \text { drink of either (1) } \mathrm{CHO} \text { ( } 75 \mathrm{~g} \\
\text { glucose and } 93 \mathrm{~g} \text { Polyjoule (CHO } \\
\text { polymer)-653 kcal); (2) } 88 \% \text { fat (cream } \\
\text { blended with milk-653 kcal) or (3) } \\
\text { water. }\end{array}$ & $\begin{array}{l}\text { SBP decreased following the CHO drink and the } \\
\text { high-fat drink but not water; there was no } \\
\text { difference in the magnitude of the decrease } \\
\text { between the CHO and fat drinks. The onset of the } \\
\text { SBP fall was slower after the fat drink ( } 26.5 \pm 17.1 \\
\text { min vs. } 13.0 \pm 11.7 \text { min). }\end{array}$ \\
\hline Visvanathan et al. [50] & 2005 & $\begin{array}{l}10 \text { healthy older participants, } 4 \mathrm{M} ; 6 \mathrm{~F} \\
\text { aged } 72.2 \pm 1.50 \text { years }\end{array}$ & Randomized crossover study & $\begin{array}{l}300 \mathrm{~mL} \text { of either } 50 \mathrm{~g} \text { glucose, } 50 \mathrm{~g} \\
\text { sucrose, } 50 \mathrm{~g} \text { fructose or water }+30 \mathrm{~mL} \\
\text { lemon juice }\end{array}$ & $\begin{array}{l}\text { SBP decreased significantly following glucose } \\
(-3.96 \pm 1.38 \mathrm{mmHg}) \text { and sucrose }(-3.03 \pm 1.37 \\
\mathrm{mmHg}) \text { ingestion, increased non-significantly } \\
\text { following fructose ingestion }(2.59 \pm 1.62 \mathrm{mmH}) \text {. } \\
\text { The decrease in SBP occurred earlier after glucose } \\
\text { than sucrose ingestion ( } 7.33 \pm 2.19 \text { vs. } 21.0 \pm 4.30 \\
\mathrm{~min}) .\end{array}$ \\
\hline
\end{tabular}


Table 1. Cont.

\begin{tabular}{|c|c|c|c|c|c|}
\hline Study & Year & Participant Characteristics & Study Design & Test Meal & Effects on Blood Pressure \\
\hline Wu et al. [88] & 2017 & $\begin{array}{l}\text { Study A: } 16 \text { participants with T2DM, } \\
\text { 11M: } 5 \mathrm{~F}, 65.5 \pm 2.4 \text { years. } \\
\text { Study B: } 9 \text { participants with T2DM, all } \\
\text { M, aged } 63.8 \pm 2.6 \text { years }\end{array}$ & Randomized crossover study & $\begin{array}{c}\text { Study A: vildagliptin }(50 \mathrm{mg}) \text { or } \\
\text { placebo was given } 60 \mathrm{~min} \text { before ID } \\
\text { glucose infusion at } 2 \text { or } 4 \mathrm{kcal} / \mathrm{min} \text { (ID2 } \\
\text { or ID4). } \\
\text { Study B: Participants received } \\
\text { metformin ( } 850 \mathrm{mg} \text { ) or placebo for } 7 \\
\text { days. On the study day, metformin } \\
\text { (850 mg) or placebo was given } 30 \mathrm{~min} \\
\text { before ID2. }\end{array}$ & $\begin{array}{l}\text { Study A: SBP and DBP decreased after } \\
\text { vildagliptin, but not after placebo, without any } \\
\text { difference between ID2 and ID4. } \\
\text { Study B: SBP and DBP decreased on both days } \\
\text { without any difference between metformin and } \\
\text { placebo. }\end{array}$ \\
\hline
\end{tabular}

T2DM = type 2 diabetes; $\mathrm{BP}=$ blood pressure; $\mathrm{SBP}=$ systolic blood pressure; $\mathrm{DBP}=$ diastolic blood pressure; $\mathrm{HR}=$ heart rate; $\mathrm{ID}=$ intraduodenal; $\mathrm{MAP}=$ mean arterial pressure; $\mathrm{PD}=$ Parkinson's disease; MSA = multi-system atrophy; $\mathrm{PPH}=$ postprandial hypotension; $\mathrm{OH}=$ orthostatic hypotension; $\mathrm{CHO}=$ carbohydrate; GLP-1 = glucagon-like peptide-1; AUC = area under the curve; $\mathrm{NS}=$ not significant; $\mathrm{M}=$ male; $\mathrm{F}$ = female. 


\subsubsection{Intraduodenal Glucose Infusion}

When the protective mechanism of gastric distension [86,87] is bypassed by infusing glucose directly into the duodenum, the fall in BP is greater compared to oral glucose in healthy older participants [54]. Vanis et al. showed that gastric distension, by as little as $100 \mathrm{~mL}$ water, could mitigate the fall in BP induced by ID glucose in healthy older participants, supporting the potential use of non-nutritive gastric distension in the management of PPH [87]. ID glucose-induced reductions in BP are observed in both older people $[54,75,81]$ and patients with T2DM $[76,85,88]$. The hypotensive response to ID glucose depends primarily on the small intestinal glucose load, but solution concentration does not appear to be important [74]. Within the normal physiological range of gastric emptying (1-4 kcal/min) [90], the rate of small intestinal delivery correlates with the magnitude of the fall in BP $[76,77,79]$. Trahair et al. reported that SBP decreased significantly during $2 \mathrm{kcal} / \mathrm{min}$ and $3 \mathrm{kcal} / \mathrm{min}$ glucose infusions, but not during $1 \mathrm{kcal} / \mathrm{min}$ glucose infusion; indicating that a threshold for the fall occurs between 1-2 kcal/min [91]. On the contrary, young healthy participants with sufficient cardiovascular responses remain normotensive [79] or become only slightly hypotensive [81] after ID glucose infusion. There is no difference in postprandial BP following ID glucose infusion between young healthy and obese groups [80].

\subsubsection{Management of PPH}

Due to its ability to induce a prominent hypotensive response, several studies investigating non-pharmacological $[63,67,68,84,86,87]$ and pharmacological $[18,55,57-61,64,65,83,85,88]$ approaches to the management of PPH have used glucose as test meals. Interventions based on slowing gastric emptying $[63,84]$ and small intestinal absorption of nutrients [82] attenuate the postprandial fall in BP. Guar gum, a vegetable-based, gel-forming non-absorbable carbohydrate, commonly used as a bulking agent, delays gastric emptying, slows the intestinal absorption of glucose and, accordingly, attenuates the magnitude of the fall in BP after oral and ID glucose $[13,63,84]$. Intermittent walking may also be effective in preventing PPH induced by glucose ingestion $[67,68]$. In terms of the pharmacologic management of $\mathrm{PPH}$, numerous medications have been tested. One study has shown that maximal postprandial fall in sitting SBP after a standardized $400 \mathrm{kcal}$ glucose drink is attenuated by caffeine [55], although the benefits of caffeine as a treatment for PPH are inconsistent and largely empirical. The effects of the somatostatin analogue, octreotide, in attenuating the fall in BP after oral glucose has been demonstrated in three studies $[58,60,61]$. These effects are not mediated via the inhibition of insulin secretion [61]. Voglibose, an alpha-glucosidase inhibitor, is effective in attenuating PPH in neurologic patients [65]. More recently, GLP-1 based therapy has drawn more attention. In a placebo-controlled study, intravenous GLP-1 infusion $\left(0.9 \mathrm{pmol} \mathrm{kg} \mathrm{g}^{-1} \cdot \mathrm{min}^{-1}\right)$ in 14 healthy older individuals and 10 patients with T2DM, resulted in the slowing of gastric emptying and attenuation in the fall in BP following ingestion of a radiolabelled $75 \mathrm{~g}$ glucose drink [16]. GLP-1 also reduces the maximum fall in SBP in response to ID glucose [18]. Both short-acting GLP-1 receptor agonists, exenatide [85] and lixisenatide [64], known to slow gastric emptying, markedly attenuate the decrease in BP compared to placebo. In contrast, the dipeptidyl peptidase-4 inhibitor (DPP-4), vildagliptin, known to block the degradation of the incretin hormones GLP-1 and GIP, did not attenuate the fall in SBP and DBP during ID glucose administration compared with placebo in T2DM [88]. Recent evidence suggests that GIP may have detrimental effects to lower postprandial $\mathrm{BP}$ and it is possible that the beneficial effects of GLP-1 by DPP-4 inhibition were nullified by GIP. The effect of the anti-diabetic medication, metformin, has also been evaluated in two studies $[38,88]$, but the outcomes are inconsistent and more studies are warranted. Other investigators have reported that the antihypertensive, nitrendipine [59], or a combination of selective $\alpha 1$ and $\beta 1$-adrenergic agonists [57], might attenuate the postprandial fall in BP after glucose ingestion, while the antiemetic drug, granisetron, a 5-HT3 antagonist, [83] has no benefit in the management of PPH. 


\subsection{Fructose}

Fructose, a monosaccharide found in fruit, honey, and some vegetables [2], may be preferred over glucose by consumers and cooks due to its intrinsically greater sweetness and ability to improve the appearance and texture of baked goods [92]. Fructose has been used increasingly as an alternative to glucose or sucrose [93-95] in several processed foods and beverages, especially in diets targeting patients with T2DM, as it provides fewer calories for the same level of sweetness as glucose $[96,97]$. In contrast to glucose, the metabolism of fructose primarily occurs in the liver, entering cells in an insulin-independent fashion [98]. Fructose is not an insulin secretagogue [98], inducing a substantially lower glycaemic response compared with glucose [95]. However, although there is no clear consensus in the literature, the potential for increased de novo lipogenesis from excessive fructose intake, particularly in those with insulin resistance, has raised the concern regarding the widespread use of this monosaccharide [99]. Compared with glucose, fructose is absorbed more slowly from the intestine $[100,101]$. There has been a total of five studies relating to the effects of oral fructose on postprandial BP in a range of cohorts including in healthy participants $[39-41,50,89]$ and hypertensive patients [41] (Table 2).

Some studies have demonstrated no change in BP in healthy young [41] and older participants [50] as well as those with hypertension [41] following ingestion of fructose. In healthy older people, SBP decreased significantly from baseline following glucose: $-3.96 \pm 1.38 \mathrm{mmHg}$ but not after the fructose drink: $2.59 \pm 1.62 \mathrm{mmHg}$ [41] (Figure 3). Two other studies reported an increase in BP in healthy young participants following ingestion of fructose $[39,40]$. This may be due to the slower intestinal absorption rate of fructose and lower glycaemic response compared with glucose [102,103], which may also result in a limited increase in SMA blood flow. However, there have been no studies comparing the difference in postprandial intestinal vascular perfusion following oral glucose and fructose. In addition, due to the lower insulinotropic effects of fructose compared with glucose and sucrose [104], effects on total vascular peripheral resistance may be mitigated $[39,89]$.
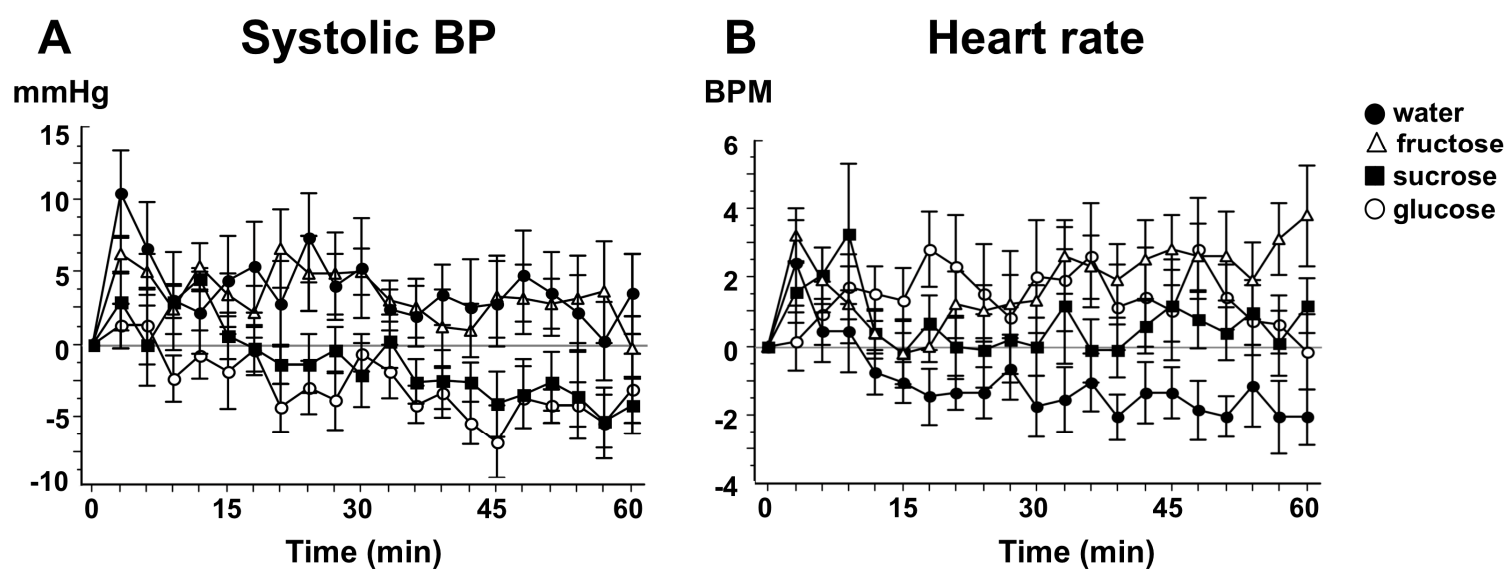

Figure 3. Change from baseline in (A) Systolic blood pressure (BP) and (B) Heart rate in 10 healthy older people following ingestion of four different study drinks $(\bigcirc$, glucose; $\mathbf{\square}$, sucrose; $\Delta$, fructose; water). Values are means \pm SEM [50]. 
Table 2. Studies relating to the effects of other nutritive sweeteners on blood pressure.

\begin{tabular}{|c|c|c|c|c|c|c|}
\hline Study & Year & Participant Characteristics & Study Design & $\begin{array}{l}\text { Sweeteners Assessed } \\
\text { rather than Glucose }\end{array}$ & Test Meal & Effects on Blood Pressure \\
\hline Brown et al. [39] & 2008 & $\begin{array}{l}15 \text { healthy normal-weight volunteers, } \\
9 \mathrm{M}: 6 \mathrm{~F} \text {, aged } 24 \pm 1 \text { years }\end{array}$ & $\begin{array}{l}\text { Randomized } \\
\text { crossover study }\end{array}$ & Fructose & $\begin{array}{l}500 \mathrm{~mL} \text { of either water, } 60 \mathrm{~g} \text { glucose, or } \\
60 \mathrm{~g} \text { fructose. }\end{array}$ & $\begin{array}{l}\text { Oral fructose, but not glucose, significantly increased SBP } \\
\text { and DBP. The maximum rise in SBP after fructose was } 6.2 \\
\pm 0.8 \mathrm{mmHg} \text {. }\end{array}$ \\
\hline Charriere et al. [89] & 2017 & $\begin{array}{c}9 \text { young healthy men, aged } 24 \pm 1 \\
\text { years }\end{array}$ & $\begin{array}{l}\text { Randomized } \\
\text { crossover study }\end{array}$ & Galactose, fructose & $\begin{array}{l}500 \mathrm{~mL} \text { of water containing } 60 \mathrm{~g} \text { of } \\
\text { either glucose, fructose or galactose. }\end{array}$ & $\begin{array}{l}\text { The increase in SBP after fructose }(7-8 \mathrm{mmHg}) \text { was } \\
\text { greater than after glucose ( } 4-5 \mathrm{mmHg}) \text { or galactose }(2-3 \\
\mathrm{mmHg}) \text {. DBP increased to a greater extent with fructose } \\
(\sim 5 \mathrm{mmHg}) \text {, compared to non-significant increases of } \\
\text { only } 2-3 \mathrm{mmH} \text { a fter glucose or galactose. }\end{array}$ \\
\hline Gentilcore et al. [105] & 2005 & $\begin{array}{l}8 \text { healthy older participants, } 5 \mathrm{M}: 3 \mathrm{~F} \text {, } \\
\text { aged } 65-79 \text { years }\end{array}$ & $\begin{array}{l}\text { Randomized } \\
\text { crossover study }\end{array}$ & Sucrose & $\begin{array}{c}300 \mathrm{~mL} \text { drink of } 100 \mathrm{~g} \text { sucrose and } 30 \\
\mathrm{~mL} \text { lemon juice with or without } 100 \\
\text { mg acarbose }\end{array}$ & $\begin{array}{l}\text { There was a fall in SBP and DBP on the control day while } \\
\text { there was an overall increase in SBP on the acarbose day. }\end{array}$ \\
\hline Gentilcore et al. [106] & 2011 & $\begin{array}{l}8 \text { healthy older participants, } 4 \mathrm{M}: 4 \mathrm{~F}, \\
\text { aged } 66-77 \text { years }\end{array}$ & $\begin{array}{l}\text { Randomized } \\
\text { crossover study }\end{array}$ & Sucrose & $\begin{array}{l}\text { ID infusion of sucrose }(100 \mathrm{~g} / 300 \mathrm{~mL}) \\
\text { at } \sim 6 \mathrm{kcal} / \mathrm{min} \text { with or without } \\
\text { acarbose }(100 \mathrm{mg}) \text {, over } 60 \mathrm{~min} .\end{array}$ & $\begin{array}{c}\text { There were significant falls in SBP (maximum fall: } 11.2 \pm \\
2.0 \mathrm{mmHg} \text { ) during control, but not after acarbose. The } \\
\text { fall in DBP was greater after control (10.9 } \pm 0.9 \mathrm{mmHg}) \\
\text { than after acarbose }(8.1 \pm 1.5 \mathrm{mmHg}) .\end{array}$ \\
\hline Grasser et al. [40] & 2014 & $\begin{array}{l}12 \text { healthy young adults, } 7 \mathrm{M}: 5 \mathrm{~F} \text {, aged } \\
22.0 \pm 0.4 \text { years }\end{array}$ & $\begin{array}{l}\text { Randomized } \\
\text { crossover study }\end{array}$ & Fructose, sucrose & $\begin{array}{l}500 \mathrm{~mL} \text { drink of either } 60 \mathrm{~g} \text { sucrose, } 60 \\
\mathrm{~g} \text { glucose, } 60 \mathrm{~g} \text { fructose or } 30 \mathrm{~g} \\
\text { fructose. }\end{array}$ & $\begin{array}{l}\text { Ingestion of fructose }(60 \text { or } 30 \mathrm{~g}) \text { elevated SBP, DBP and } \\
\text { MAP. Ingestion of glucose elevated SBP. Ingestion of } \\
\text { sucrose showed no BP changes. The increases in DBP } \\
\text { and MAP were significantly higher for fructose ( } 60 \text { or } 30 \\
\text { g) than for either glucose or sucrose. The increase in SBP } \\
\text { was significantly higher for fructose than for sucrose. }\end{array}$ \\
\hline Jansen et al. [41] & 1987 & $\begin{array}{c}10 \text { young normotensive people, aged } \\
28 \pm 1 \text { years (YN), } 10 \text { young } \\
\text { hypertensive patients, aged } 44 \pm 2 \\
\text { years (YH), } 10 \text { elderly normotensive } \\
\text { people aged } 75 \pm 2 \text { years (EN), } 10 \\
\text { elderly hypertensive patients aged } 75 \\
\pm 1 \text { years (EH) }\end{array}$ & $\begin{array}{l}\text { Randomized } \\
\text { crossover study }\end{array}$ & Fructose & $\begin{array}{l}300 \mathrm{~mL} \text { drink of either } 75 \mathrm{~g} \text { glucose or } \\
75 \mathrm{~g} \text { fructose }\end{array}$ & $\begin{array}{l}\text { Glucose decreased MAP significantly in the EH, EN and } \\
\text { YH group. After fructose, BP remained unchanged in } \\
4 \text { groups. }\end{array}$ \\
\hline Mathias et al. [43] & 1989 & $\begin{array}{l}6 \text { patients with chronic autonomic } \\
\text { failure (CAF), } 4 \mathrm{M}: 2 \mathrm{~F} \text {, aged } 42-68 \text { years; } \\
6 \text { age-matched participants without } \\
\text { CAF, aged } 45-70 \text { years; and } 8 \text { normal } \\
\text { participants, all M, aged } 28-35 \text { years }\end{array}$ & $\begin{array}{l}\text { Randomized parallel } \\
\text { study }\end{array}$ & Xylose & $\begin{array}{l}\text { An iso-osmotic solution of glucose }(1 \\
\mathrm{g} / \mathrm{kg} \text { body weight) or xylose }(0.83 \mathrm{~g} / \mathrm{kg} \\
\text { body weight) in } 250 \mathrm{~mL} \text { water. }\end{array}$ & $\begin{array}{l}\text { Xylose caused a lower and more transient fall in BP than } \\
\text { glucose in patients with CAF }(15 \pm 6 \% \text { vs. } 34 \pm 7 \%) \text {. After } \\
\text { glucose, there was a substantial fall in } 6 \text { age-matched } \\
\text { participants but a minimal change in } 8 \text { male } \\
\text { normal participants. }\end{array}$ \\
\hline
\end{tabular}


Table 2. Cont.

\begin{tabular}{|c|c|c|c|c|c|c|}
\hline Study & Year & Participant Characteristics & Study Design & $\begin{array}{l}\text { Sweeteners Assessed } \\
\text { rather than Glucose }\end{array}$ & Test Meal & Effects on Blood Pressure \\
\hline Robinson et al. [45] & 1992 & $\begin{array}{l}5 \text { people with age-related } \mathrm{OH}, 2 \mathrm{M}: 3 \mathrm{~F}, \\
\text { aged } 73-88 \text { years, } 3 \text { people with } \\
\text { autonomic failure, } 1 \mathrm{M}: 2 \mathrm{~F} \text {, aged } 72-79 \\
\text { years and } 5 \text { controls, } 2 \mathrm{M}: 3 \mathrm{~F} \text {, aged } \\
72-86 \text { years }\end{array}$ & $\begin{array}{l}\text { Randomized } \\
\text { crossover study }\end{array}$ & Xylose & $\begin{array}{c}50 \mathrm{~g} \text { glucose or } 42 \mathrm{~g} \text { xylose in } 100 \mathrm{~mL} \\
\text { water }\end{array}$ & $\begin{array}{l}\text { There were no significant BP changes in the control } \\
\text { group. In OH and autonomic failure groups, the SBP } \\
\text { decreased comparably following glucose and xylose, } \\
\text { DBP was lowered } 60-90 \text { min after glucose. }\end{array}$ \\
\hline $\begin{array}{c}\text { Teunissen-Beekman et al. } \\
\text { [107] }\end{array}$ & 2014 & $\begin{array}{l}48 \text { participants, } 31 \mathrm{M} ; 17 \mathrm{~F} \text {, aged } 58 \pm 1 \\
\text { (SEM) years }\end{array}$ & $\begin{array}{l}\text { Randomized } \\
\text { crossover study }\end{array}$ & Maltodextrin, sucrose & $\begin{array}{l}\text { Test drink of } 70 \mathrm{~g} \text { either protein (pea } \\
\text { protein isolate, milk protein isolate, } \\
\text { egg white protein isolate or mixed } \\
\text { protein), sucrose or maltodextrin. }\end{array}$ & $\begin{array}{l}\text { DBP and MAP were significantly decreased after } \\
\text { maltodextrin, but not after protein mix or sucrose. SBP } \\
\text { was not significantly changed after any of the meals. }\end{array}$ \\
\hline Vanis et al. [49] & 2011 & $\begin{array}{c}8 \text { healthy older participants, } 6 \mathrm{M}: 2 \mathrm{~F}, \\
\text { aged } 65-75 \text { years }\end{array}$ & $\begin{array}{l}\text { Randomized } \\
\text { crossover study }\end{array}$ & Xylose & $\begin{array}{l}300 \mathrm{~mL} \text { drink of water, } 50 \mathrm{~g} \text { glucose or } \\
50 \mathrm{~g} \text { D-xylose. }\end{array}$ & $\begin{array}{l}\text { There was a fall in SBP after glucose drink and no change } \\
\text { after xylose or water drink. }\end{array}$ \\
\hline Visvanathan et al. [50] & 2005 & $\begin{array}{l}10 \text { healthy older participants, } 4 \mathrm{M}: 6 \mathrm{~F} \\
\text { aged } 72.2 \pm 1.50 \text { years }\end{array}$ & $\begin{array}{l}\text { Randomized } \\
\text { crossover study }\end{array}$ & Fructose, sucrose & $\begin{array}{l}300 \mathrm{~mL} \text { of either } 50 \mathrm{~g} \text { glucose, } 50 \mathrm{~g} \\
\text { sucrose, } 50 \mathrm{~g} \text { fructose or water }+30 \mathrm{~mL} \\
\text { lemon juice }\end{array}$ & $\begin{array}{l}\text { SBP decreased significantly following glucose }(-3.96 \pm \\
1.38 \mathrm{mmHg}) \text { and sucrose }(-3.03 \pm 1.37 \mathrm{mmHg}) \text {, but not } \\
\text { fructose, ingestion }(2.59 \pm 1.62 \mathrm{mmHg}) \text {. The decrease in } \\
\text { SBP occurred earlier after glucose than sucrose ingestion } \\
(7.33 \pm 2.19 \text { vs. } 21.0 \pm 4.30 \mathrm{~min}) \text {. }\end{array}$ \\
\hline
\end{tabular}

T2DM = type 2 diabetes; $\mathrm{BP}=$ blood pressure; $\mathrm{SBP}=$ systolic blood pressure; $\mathrm{DBP}=$ diastolic blood pressure; $\mathrm{ID}=$ intraduodenal; $\mathrm{MAP}=$ mean arterial pressure; $\mathrm{MSA}=$ multi-system atrophy; $\mathrm{PPH}=$ postprandial hypotension; $\mathrm{OH}=$ orthostatic hypotension. 


\subsection{Sucrose}

Sucrose is a common table sugar produced naturally in fruit and vegetables and often added to many processed foods [108]. Sucrose tastes sweeter than glucose, but not as sweet as fructose. The digestion of sucrose is initiated in the mouth and stomach, but the majority of this disaccharide is hydrolysed and digested in the small intestine by the $\alpha$-glucosidase sucrase to release an equimolar mixture of glucose and fructose [109]. There have been five studies relating to effects of sucrose on postprandial BP in healthy participants $[40,50,105-107]$ (Table 2): four used an oral load $[40,50,105,107]$ while one study used an ID infusion [106].

The cardiovascular effects of sucrose are more similar to those observed following glucose than fructose, despite its equimolar constitution [110]. Visvanathan et al. reported that ingestion of $50 \mathrm{~g}$ sucrose or $50 \mathrm{~g}$ glucose induced a comparable fall in SBP in healthy elderly individuals, but the decrease in SBP occurred earlier after glucose, than sucrose, ingestion [50] (Figure 3). This may be due to the fact that sucrose is a disaccharide, requiring hydrolysis prior to mediating cardiovascular effects [50]. In comparison, a $60 \mathrm{~g}$ sucrose drink had no substantial impact on BP in healthy young participants [40], which may be due to the more effective postprandial haemodynamic responses compared with an older population. The $\alpha$-glucosidase inhibitor, acarbose, is approved for the treatment of T2DM and is known to reduce postprandial glycaemia [111] through stimulation of GLP-1 [112], and slowing of gastric emptying $[105,113]$. In healthy older participants, acarbose substantially decreases falls in SBP and DBP induced by not both oral [105], and ID [106] sucrose, loads.

\section{4. $\mathrm{D}-X y l o s e$ and Xylitol}

Xylose, a monosaccharide of the aldopentose type consists of five carbon atoms and is derived from wood. The free aldehyde group reduces its sweetness and makes it a widely used alternative for glucose in the diabetic diet. Xylose is primarily absorbed by passive penetration through the wall of human duodenum and jejunum [114], with the remainder delivered to the ileum and the colon. Xylose is emptied from the stomach at a similar rate to glucose [49]. There have been three studies related to effects of oral xylose on postprandial BP in healthy older participants [43,45,49], orthostatic hypotension $(\mathrm{OH})$ [45] and autonomic failure [43,45] patients (Table 2). While Mathias et al. [43] reported xylose induced a milder and more transient fall in postprandial BP compared with glucose in those with chronic autonomic failure, Robinson et al. reported that glucose and xylose ingestion induced a comparable fall in SBP at 60-90 min in supine patients diagnosed with $\mathrm{OH}$ and autonomic failure [45]. In a previous study by our group, designed to compare effects of glucose and xylose on BP, gastric emptying and incretin hormones, xylose emptied from the stomach at a comparable rate to glucose, with a greater and more prolonged effect on GLP-1 secretion in healthy older participants [49]. However, there was no change in postprandial BP observed, potentially due to the effects of GLP-1 in delaying the nutrient absorption in the distal small intestine. These findings support the replacement of glucose by xylose as a simple management to decrease the postprandial fall in BP [49].

Reduction of xylose by catalytic hydrogenation produces xylitol [115]. Xylitol has a comparable sweetness to sucrose and contains less than one-third of calories in conventional sugars. As xylitol is metabolized in an insulin-independent manner, its use has been widely advocated in the prevention and control of hyperglycaemia, obesity, and related metabolic disorders [116,117]. However, xylitol is often associated with diarrhoea due to its stimulatory effect on the intestinal transit and the release of plasma motilin [118]. Salminen et al. [118] reported that $30 \mathrm{~g}$ xylitol solution was emptied from the stomach at a significantly slower rate than a $30 \mathrm{~g}$ of glucose, suggesting that xylitol might protect against PPH, although further studies are required.

\subsection{Erythritol}

Erythritol, a four-carbon pentose, is made through food fermentation but may occur naturally in a wide variety of fruits and mushrooms. Erythritol has a sweetness of $\sim 70 \%$ compared with sucrose 
and has minimal insulinotropic effects $[119,120]$. Nevertheless, the effect erythritol on BP has not been studied. In patients with T2DM, acute consumption of erythritol has vasoprotective effects by decreasing oxidative stress and endothelial dysfunction [121].

\subsection{Maltose and Maltodextrin}

Maltose, or malt sugar, a disaccharide composed of two glucose units, is an intermediate in the intestinal breakdown of glycogen and starch and is found in germinating grains [122]. Maltodextrin is a nutritive saccharide polymer consisting of D-glucose units with a low sweetness (dextrose equivalency of less than 20). It is often used in the production of soft drinks, candy, and processed food [123]. Both maltose [124] and maltodextrin [125] are emptied more slowly from the stomach compared with sucrose, although there is no significant difference in gastric emptying between maltodextrin and glucose [125]. To our knowledge, there have been no studies investigating the effects of maltose on postprandial BP. There has been only one study related to effects of oral maltodextrin on postprandial BP in healthy older participants [107] (Table 2) in which postprandial MAP and DBP were shown to be greater after sucrose compared to after maltodextrin [107]. The underlying mechanisms remain unclear [107].

\subsection{Tagatose}

Tagatose has a very similar structure to sucrose, is commonly found in dairy products [126] and is low calorie; only 20 to $25 \%$ of ingested D-tagatose is absorbed through the small intestine to provide $1.5 \mathrm{kcal} / \mathrm{g}$ [127]. The remaining ingested tagatose is fermented into short-chain fatty acids by colonic bacteria $[2,128]$. Tagatose has a substantial hypoglycaemic effect without major adverse effects, contributing to its potential therapeutic benefits in obese people and patients with T2DM [129-132]. While tagatose has been shown to slow gastric emptying [133,134], to our knowledge there is no information regarding the effect of tagatose on BP.

\section{Non-Nutritive Sweeteners}

\subsection{Sucralose}

Sucralose, a noncaloric artificial sweetener with a sweetness approximately 600 times higher than that of sucrose [135], is increasingly being used as a sugar substitute to reduce calorie intake, especially in obese people and those with diabetes [3]. It is almost unabsorbed in the small intestine and excreted in the faeces in both animal $[136,137]$ and human [138] experiments. In healthy participants, sucralose empties at a similar rate to saline [139].

There have been two studies investigating effects of sucralose on postprandial BP [78,140] (Table 3). Kazmi et al. reported that there was no change in BP following oral sucralose in 200 young healthy participants compared to saline. In a recent study by our group, while ID infusion of glucose at a rate of $3 \mathrm{kcal} / \mathrm{min}$ induced a substantial fall in postprandial BP and increase in SMA blood flow in 12 healthy older participants, there were no significant effects on BP or splanchnic blood flow following an ID infusion of sucralose [78] (Figure 4). Studies by others have shown that sucralose has no effect on insulin, GLP-1 or GIP secretion or SMA blood flow [139,141], supporting a therapeutic role for sucralose in the dietary management of PPH. 
Table 3. Studies relating to the effects of non-nutritive sweeteners on blood pressure.

\begin{tabular}{|c|c|c|c|c|c|c|}
\hline Study & Year & Participant Characteristics & Study Design & $\begin{array}{c}\text { Non-Nutritive } \\
\text { Sweeteners Assessed }\end{array}$ & Test Meal & Effects on Blood Pressure \\
\hline Kazmi et al. [140] & 2017 & $\begin{array}{c}200 \text { students divided equally } \\
\text { into } 4 \text { groups: A (aged } 18.82 \pm \\
0.80 \text { years), B: (aged } 18.60 \pm \\
0.57), \text { C (aged } 18.64 \pm 0.59) \text { and } \\
\text { D }(18.64 \pm 0.59)\end{array}$ & Parallel study & $\begin{array}{c}\text { Aspartame, } \\
\text { Acesulfame-K, } \\
\text { sucralose }\end{array}$ & $\begin{array}{c}\text { Group A (control): } 10 \mathrm{~g} \text { of } \\
\text { cellulose. Group B: } 0.36 \mathrm{gm}(5 \\
\mathrm{mg} / \mathrm{kg}) \text { sucralose. Group C: } 10.8 \mathrm{~g} \\
(150 \mathrm{mg} / \mathrm{kg}) \text { aspartame. Group D: } \\
3.24 \mathrm{~g}(45 \mathrm{mg} / \mathrm{kg}) \text { Acesulfame-K. }\end{array}$ & $\begin{array}{l}\text { There was no difference in BP between group A } \\
\text { and B. SBP was lower at } 60,90 \text { and } 120 \text { min for } \\
\text { group C; and at } 60 \text { min for group D compared to } \\
\text { control. }\end{array}$ \\
\hline Pham et al. [78] & 2018 & $\begin{array}{l}12 \text { healthy participants, } 6 \mathrm{M}: 6 \mathrm{~F} \\
\text { aged } 73.2 \pm 1.1 \text { (SEM) years }\end{array}$ & $\begin{array}{l}\text { Randomized } \\
\text { crossover study }\end{array}$ & Sucralose & $\begin{array}{l}\text { ID infusion of either glucose }(25 \%, \\
\sim 1400 \mathrm{mOsmol} / \mathrm{L}), \text { sucralose }(4 \\
\mathrm{mmol} / \mathrm{L}, \sim 300 \mathrm{mOsmol} / \mathrm{L}) \text { or saline } \\
(0.9 \%, \sim 300 \mathrm{mOsmol} / \mathrm{L}) \text { at a rate of } \\
3 \mathrm{~mL} / \mathrm{min} \text { for } 60 \mathrm{~min} \text { followed by } \\
\text { ID saline for a further } 60 \mathrm{~min} .\end{array}$ & $\begin{array}{l}\text { MAP decreased during glucose but not during } \\
\text { sucralose or saline. By } t=60 \mathrm{~min}, \mathrm{MAP} \text { was } \\
\text { lower after glucose }(85.9 \pm 2.8 \mathrm{mmHg}) \text { than after } \\
\text { sucralose (93.1 } \pm 2.2 \mathrm{mmHg}) \text { infusions without } \\
\text { significant difference between sucralose and } \\
\text { saline infusions. }\end{array}$ \\
\hline
\end{tabular}

$\mathrm{BP}=$ blood pressure; $\mathrm{MAP}=$ mean arterial pressure; $\mathrm{ID}=$ intraduodenal 

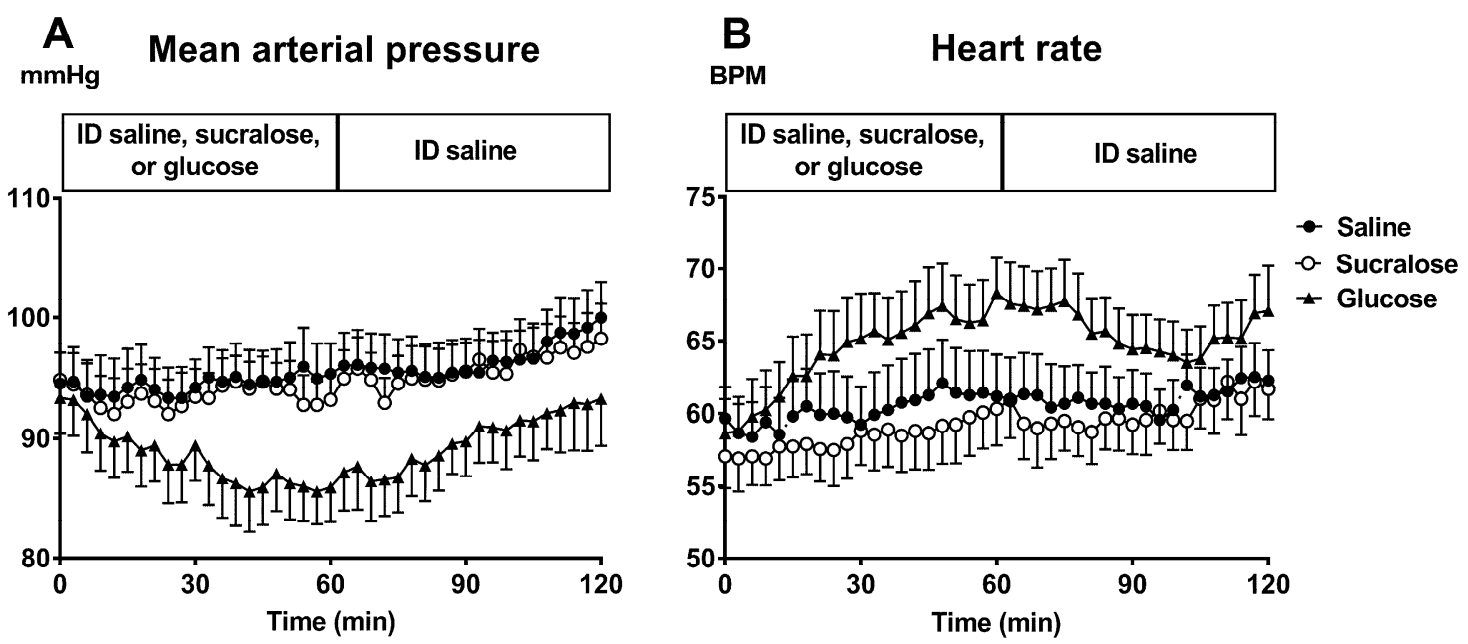

Figure 4. (A) Mean arterial pressure (MAP) and (B) Heart Rate in 12 healthy older subjects after intraduodenal (ID) infusion of glucose $(\boldsymbol{\Lambda})$, sucralose (o), and saline $(\bullet)$. Values are means \pm SEM. MAP: $p<0.05$ for glucose compared with sucralose or saline, and $p=1.0$ for sucralose compared with saline. Heart rate: $p<0.05$ for glucose compared with sucralose, $p=0.07$ for glucose compared with saline, and $p=1.0$ for sucralose compared with saline [78].

\subsection{Acesulfame-K}

Acesulfame-K, a non-nutritive sweetener, was invented in 1967 by the pharmaceutical company, Hoechst AG. It is estimated to be 200 times sweeter than sucrose and is often mixed with sucralose or aspartame in foods and beverages [28]. In 2009, Brown et al. reported that the GLP-1 release increased by more than $30 \%$ after drinking "diet soda", comprising sucralose, aspartame and Acesulfame-K compared to carbonated water [142]. However, this finding was not replicated in subsequent studies $[141,143]$. Acesulfame-K alone or combined has no effect on GLP-1 secretion, insulin, or blood glucose. There has been only one study investigating the effect of Acesulfame-K on BP [140] (Table 3). Kazmi et al. reported that SBP was lower at $60 \mathrm{~min}$ following the ingestion of $3.24 \mathrm{gm}(45 \mathrm{mg} / \mathrm{kg})$ of Acesulfame-K in 50 healthy young participants compared to controls. The design of that study was, however, suboptimal, as SBP and DBP were only measured at 30, 60, 90 and 120 min and the baseline measurement was not taken into account.

\subsection{Aspartame}

Aspartame, a methyl ester of aspartic acid and phenylalanine dipeptide, was approved as a non-nutritive sweetener in 1996 by the FDA. It is 160 to 220 times sweeter than sucrose and the only non-nutritive sweetener providing energy $(4 \mathrm{kcal} / \mathrm{g})$. However, due to the intense sweetness, only a tiny quantity is used in foods and soft drinks and the number of calories is negligible, hence, it is considered 'non-nutritive' [2,3]. Little et al. [144] demonstrated that the gastric emptying of aspartame does not differ from that of water. There has been only one study investigating the effect of aspartame on BP [140] (Table 3). In this study, young healthy participants experienced falls in SBP at 60, 90 and $120 \mathrm{~min}$ following the ingestion of $10.8 \mathrm{~g}(150 \mathrm{mg} / \mathrm{kg}$ ) aspartame compared to $10 \mathrm{~g}$ of cellulose (control) $(109.82 \pm 11.39$ vs. $116.92 \pm 8.98,112.54 \pm 11.18$ vs. $117.84 \pm 10.2$ and $112.02 \pm 10.54$ vs. $117.16 \pm$ 8.62 respectively) [140]. Again, the design of that study was, suboptimal, as SBP and DBP were only measured at 30, 60, 90 and $120 \mathrm{~min}$ and the baseline measurement was not taken into account.

\subsection{Saccharin}

Saccharin is the oldest non-nutritive sweetener that is currently approved, is not metabolized in humans and is considered non-carcinogenic [2,3]. To date, there are no studies investigating the acute effects of saccharin on BP. 


\subsection{Steviol Glycoside}

Steviol glycoside sweeteners are extracted and purified from the leaves of the Stevia rebaudiana Bertoni plant, which is native to South America. Its sweet potency is reported to be 200 to 400 times sweeter than table sugar $[145,146]$. Steviol glycoside has been categorized as a non-caloric sweetener and widely used in the food and soft drinks consumed by millions of people and is well tolerated [126]. In one study, postprandial blood glucose and insulin levels were significantly lower when healthy lean and obese participants consumed a steviol glycoside preload before meals compared with an isocaloric sucrose preload [147]. Another study in participants with T2DM reported that steviol glycoside reduced postprandial blood glucose without a significant change in insulin levels [148]. Furthermore, steviol glycoside was also shown to significantly reduce food intake [147]. Peirera et al. [149] did not demonstrate any effect of steviol glycoside on gastric emptying of a liquid test meal in 10 male healthy volunteers. Most of the studies in the literature have evaluated the effect of long-term steviol glycoside intake on BP and demonstrated that it may be effective in decreasing SBP and DBP compared with placebo in hypertensive [150,151], but not in normotensive or hypotensive, participants $[152,153]$. However, there have been no publications evaluating the acute effect of this sweetener on postprandial BP.

\subsection{Neotame and Advantame}

Neotame is closely related to aspartame in terms of the chemical constitution. It is $7000-13,000$ times sweeter than sucrose [154]. Advantame is considered the most potent non-caloric sweetener with sweetness approximately 20,000 times greater than sucrose [154]. Advantame is derived from isovanillin and aspartame [155]. To our knowledge there have been no studies evaluating the effects of these sweeteners on BP.

\section{Conclusions}

$\mathrm{PPH}$ is associated with an increased incidence of falls, syncope, angina and transient ischaemic attacks, particularly in older people and patients with autonomic failure that is frequently secondary to diabetes mellitus and PD. For nutritive sweeteners, glucose induces the greatest fall in postprandial $\mathrm{BP}$ and should be limited in people with PPH. Most of the currently available literature indicates that non-nutritive sweeteners have little effect on BP. While pharmacological and dietary approaches are being explored, current management of PPH remains suboptimal. Our literature review supports the view that low nutritive (D-xylose, xylitol, erythritol, maltose, maltodextrin, and tagatose) and non-nutritive sweeteners could be used to replace high nutritive sweeteners (glucose, fructose, and sucrose) in the dietary management of $\mathrm{PPH}$.

Author Contributions: All authors have contributed substantially to the work and have approved the final version.

Funding: HP is supported by a Vietnam International Education Development (VIED) Scholarship and a University of Adelaide William T Southcott Research Scholarship. This research received no external funding. The salary of KLJ is funded by a University of Adelaide William T Southcott Research Fellowship.

Conflicts of Interest: The authors declare no conflict of interest.

\section{References}

1. Malik, V.S.; Willett, W.C.; Hu, F.B. Global obesity: Trends, risk factors and policy implications. Nat. Rev. Endocrinol. 2013, 9, 13. [CrossRef] [PubMed]

2. Fitch, C.; Keim, K.S. Position of the academy of nutrition and dietetics: Use of nutritive and nonnutritive sweeteners. J. Acad. Nutr. Diet. 2012, 112, 739-758. [CrossRef] [PubMed]

3. American Dietetic Association. Position of the american dietetic association: Use of nutritive and nonnutritive sweeteners. J. Am. Diet. Assoc. 2004, 104, 255-275. [CrossRef]

4. Trahair, L.G.; Horowitz, M.; Jones, K.L. Postprandial hypotension: A systematic review. J. Am. Med. Dir. Assoc. 2014, 15, 394-409. [CrossRef] [PubMed] 
5. Jansen, R.W.; Lipsitz, L.A. Postprandial hypotension: Epidemiology, pathophysiology, and clinical management. Ann. Intern. Med. 1995, 122, 286-295. [CrossRef]

6. Puisieux, F.; Bulckaen, H.; Fauchais, A.L.; Drumez, S.; Salomez-Granier, F.; Dewailly, P. Ambulatory blood pressure monitoring and postprandial hypotension in elderly persons with falls or syncopes. J. Gerontol. Ser. A Biol. Sci. Med. Sci. 2000, 55, M535-M540. [CrossRef] [PubMed]

7. Fisher, A.A.; Davis, M.W.; Srikusalanukul, W.; Budge, M.M. Postprandial hypotension predicts all-cause mortality in older, low-level care residents. J. Am. Geriatr. Soc. 2005, 53, 1313-1320. [CrossRef]

8. Zanasi, A.; Tincani, E.; Evandri, V.; Giovanardi, P.; Bertolotti, M.; Rioli, G. Meal-induced blood pressure variation and cardiovascular mortality in ambulatory hypertensive elderly patients. J. Hypertens. 2012, 30, 2125-2132. [CrossRef]

9. Aronow, W.S.; Ahn, C. Association of postprandial hypotension with incidence of falls, syncope, coronary events, stroke, and total mortality at 29-month follow-up in 499 older nursing home residents. J. Am. Geriatr. Soc. 1997, 45, 1051-1053. [CrossRef]

10. Jansen, R.W.; Peeters, T.L.; Van Lier, H.J.; Hoefnagels, W.H. The effect of oral glucose, protein, fat and water loading on blood pressure and the gastrointestinal peptides VIP and somatostatin in hypertensive elderly subjects. Eur. J. Clin. Invest. 1990, 20, 192-198. [CrossRef]

11. Jones, K.L.; Tonkin, A.; Horowitz, M.; Wishart, J.M.; Carney, B.I.; Guha, S.; Green, L. Rate of gastric emptying is a determinant of postprandial hypotension in non-insulin-dependent diabetes mellitus. Clin. Sci. 1998, 94, 65-70. [CrossRef] [PubMed]

12. Pham, H.; Phillips, L.; Trahair, L.; Hatzinikolas, S.; Horowitz, M.; Jones, K.L. Longitudinal changes in the blood pressure responses to, and gastric emptying of, an oral glucose load in healthy older subjects. J. Gerontol. A Biol. Sci. Med. Sci. 2019. [CrossRef] [PubMed]

13. Russo, A.; Stevens, J.E.; Wilson, T.; Wells, F.; Tonkin, A.; Horowitz, M.; Jones, K.L. Guar attenuates fall in postprandial blood pressure and slows gastric emptying of oral glucose in type 2 diabetes. Dig. Dis. Sci. 2003, 48, 1221-1229. [CrossRef] [PubMed]

14. Gentilcore, D.; Hausken, T.; Meyer, J.H.; Chapman, I.M.; Horowitz, M.; Jones, K.L. Effects of intraduodenal glucose, fat, and protein on blood pressure, heart rate, and splanchnic blood flow in healthy older subjects. Am. J. Clin. Nutr. 2008, 87, 156-161. [CrossRef] [PubMed]

15. Nauck, M.A. Incretin-based therapies for type 2 diabetes mellitus: Properties, functions, and clinical implications. Am. J. Med. 2011, 124, S3-S18. [CrossRef] [PubMed]

16. Trahair, L.G.; Horowitz, M.; Stevens, J.E.; Feinle-Bisset, C.; Standfield, S.; Piscitelli, D.; Rayner, C.K.; Deane, A.M.; Jones, K.L. Effects of exogenous glucagon-like peptide-1 on blood pressure, heart rate, gastric emptying, mesenteric blood flow and glycaemic responses to oral glucose in older individuals with normal glucose tolerance or type 2 diabetes. Diabetologia 2015, 58, 1769-1778. [CrossRef]

17. Meier, J.J.; Gallwitz, B.; Salmen, S.; Goetze, O.; Holst, J.J.; Schmidt, W.E.; Nauck, M.A. Normalization of glucose concentrations and deceleration of gastric emptying after solid meals during intravenous glucagon-like peptide 1 in patients with type 2 diabetes. J. Clin. Endocrinol. Metab. 2003, 88, 2719-2725. [CrossRef]

18. Trahair, L.G.; Horowitz, M.; Hausken, T.; Feinle-Bisset, C.; Rayner, C.K.; Jones, K.L. Effects of exogenous glucagon-like Peptide-1 on the blood pressure, heart rate, mesenteric blood flow, and glycemic responses to intraduodenal glucose in healthy older subjects. J. Clin. Endocrinol. Metab. 2014, 99, E2628-E2634. [CrossRef]

19. Edholm, T.; Degerblad, M.; Grybäck, P.; Hilsted, L.; Holst, J.J.; Jacobsson, H.; Efendic, S.; Schmidt, P.; Hellström, P.M. Differential incretin effects of GIP and GLP-1 on gastric emptying, appetite, and insulin-glucose homeostasis. Neurogastroenterol. Motil. 2010, 22. [CrossRef]

20. Meier, J.J.; Goetze, O.; Anstipp, J.; Hagemann, D.; Holst, J.J.; Schmidt, W.E.; Gallwitz, B.; Nauck, M.A. Gastric inhibitory polypeptide does not inhibit gastric emptying in humans. Am. J. Physiol. Endocrinol. Metab. 2004, 286, E621-E625. [CrossRef]

21. Jansen, R.W.; Hoefnagels, W.H. Hormonal mechanisms of postprandial hypotension. J. Am. Geriatr. Soc. 1991, 39, 1201-1207. [CrossRef]

22. Maule, S.; Tredici, M.; Dematteis, A.; Matteoda, C.; Chiandussi, L. Postprandial hypotension treated with acarbose in a patient with type 1 diabetes mellitus. Clin. Auton. Res. 2004, 14, 405-407. [CrossRef]

23. Dhingra, R.; Sullivan, L.; Jacques, P.; Wang, T.; Fox, C.; Meigs, J.D.; Agostino, R.B.; Gaziano, J.M.; Vasan, R.S. Soft drink consumption and risk of developing cardiometabolic risk factors and the metabolic syndrome in middle-aged adults in the community. Circulation 2007, 116, 480-488. [CrossRef] 
24. Popkin, B.M.; Hawkes, C. Sweetening of the global diet, particularly beverages: Patterns, trends, and policy responses. Lancet Diabetes Endocrinol. 2016, 4, 174-186. [CrossRef]

25. Malik, V.S.; Li, Y.; Pan, A.; De Koning, L.; Schernhammer, E.; Willett, W.C.; Hu, F.B. Long-term Consumption of sugar-sweetened and artificially sweetened beverages and Risk of mortality in US adults. Circulation 2019, 18, 2113-2125. [CrossRef]

26. Piernas, C.; Ng, S.W.; Popkin, B. Trends in purchases and intake of foods and beverages containing caloric and low-calorie sweeteners over the last decade in the United States. Pediatr. Obes. 2013, 8, 294-306. [CrossRef]

27. Johnson, R.K.; Lichtenstein, A.H.; Anderson, C.A.; Carson, J.A.; Després, J.P.; Hu, F.B.; Kris-Etherton, P.M.; Otten, J.J.; Towfighi, A.; Wylie-Rosett, J. Low-calorie sweetened beverages and cardiometabolic health: A science advisory from the american heart association. Circulation 2018, 138, e126-e140. [CrossRef]

28. Chattopadhyay, S.; Raychaudhuri, U.; Chakraborty, R. Artificial sweeteners-A review. J. Food Sci. Technol. 2014, 51, 611-621. [CrossRef]

29. US Food and Drug Administration. Additional Information about High-Intensity Sweeteners Permitted for Use in Food in the United States; US Food and Drug Administration: Silver Spring, MD, USA, 2018.

30. Perrier, J.D.; Mihalov, J.J.; Carlson, S.J. FDA regulatory approach to steviol glycosides. Food Chem. Toxicol. 2018, 122, 132-142. [CrossRef]

31. Ruiz-Ojeda, F.J.; Plaza-Díaz, J.; Sáez-Lara, M.J.; Gil, A. Effects of sweeteners on the gut microbiota: A review of experimental studies and clinical trials. Adv. Nutr. 2019, 10, S31-S48. [CrossRef]

32. Godswill, A.C. Sugar alcohols: Chemistry, production, health concerns and nutritional importance of mannitol, sorbitol, xylitol, and erythritol. Int. J. Adv. Acad. Res. 2017, 3, 32-66.

33. Moher, D.; Liberati, A.; Tetzlaff, J.; Altman, D.G. Preferred reporting items for systematic reviews and meta-analyses: The PRISMA statement. BMJ 2009, 339, b2535. [CrossRef]

34. Galant, A.L.; Kaufman, R.C.; Wilson, J.D. Glucose: Detection and analysis. Food Chem. 2015, 188, 149-160. [CrossRef]

35. Deibert, P.; Konig, D.; Kloock, B.; Groenefeld, M.; Berg, A. Glycaemic and insulinaemic properties of some German honey varieties. Eur. J. Clin. Nutr. 2010, 64, 762-764. [CrossRef]

36. Chareoansiri, R.; Kongkachuichai, R. Sugar profiles and soluble and insoluble dietary fiber contents of fruits in Thailand markets. Int. J. Food Sci. Nutr. 2009, 60 (Suppl. 4), 126-139. [CrossRef]

37. Blanco, A.; Blanco, G. Chapter 14-Carbohydrate metabolism. In Medical Biochemistry; Blanco, A., Blanco, G., Eds.; Academic Press: Cambridge, MA, USA, 2017; pp. 283-323.

38. Borg, M.J.; Jones, K.L.; Sun, Z.; Horowitz, M.; Rayner, C.K.; Wu, T. Metformin attenuates the postprandial fall in blood pressure in type 2 diabetes. Diabetes Obes. Metab. 2019, 21, 1251-1254. [CrossRef]

39. Brown, C.M.; Dulloo, A.G.; Yepuri, G.; Montani, J.P. Fructose ingestion acutely elevates blood pressure in healthy young humans. Am. J. Physiol. Regul. Integr. Comp. Physiol. 2008, 294, R730-R737. [CrossRef]

40. Grasser, E.K.; Dulloo, A.; Montani, J.P. Cardiovascular responses to the ingestion of sugary drinks using a randomised cross-over study design: Does glucose attenuate the blood pressure-elevating effect of fructose? Br. J. Nutr. 2014, 112, 183-192. [CrossRef]

41. Jansen, R.W.M.M.; Penterman, B.J.M.; Van Lier, H.J.J.; Hoefnagels, W.H.L. Blood pressure reduction after oral glucose loading and its relation to age, blood pressure and insulin. Am. J. Cardiol. 1987, 60, 1087-1091. [CrossRef]

42. Jones, K.L.; O’Donovan, D.; Russo, A.; Meyer, J.H.; Stevens, J.E.; Lei, Y.; Keogh, J.; Tonkin, A.; Horowitz, M. Effects of drink volume and glucose load on gastric emptying and postprandial blood pressure in healthy older subjects. Am. J. Physiol. Gastrointest. Liver Physiol. 2005, 289, G240-G248. [CrossRef]

43. Mathias, C.J.; da Costa, D.F.; McIntosh, C.M.; Fosbraey, P.; Bannister, R.; Wood, S.M.; Bloom, S.R.; Christensen, N.J. Differential blood pressure and hormonal effects after glucose and xylose ingestion in chronic autonomic failure. Clin. Sci. 1989, 77, 85-92. [CrossRef]

44. Nguyen, T.A.N.; Ali Abdelhamid, Y.; Weinel, L.M.; Hatzinikolas, S.; Kar, P.; Summers, M.J.; Phillips, L.K.; Horowitz, M.; Jones, K.L.; Deane, A.M. Postprandial hypotension in older survivors of critical illness. J. Crit. Care 2018, 45, 20-26. [CrossRef]

45. Robinson, B.J.; Stowell, L.I.; Purdie, G.L.; Palmer, K.T.; Johnson, R.H. Autonomic responses to carbohydrate ingestion and head-up tilt in elderly subjects with orthostatic hypotension. Clin. Auton. Res. 1992, 2, 309-316. [CrossRef] 
46. Trahair, L.G.; Horowitz, M.; Jones, K.L. Postprandial hypotension is associated with more rapid gastric emptying in healthy older individuals. J. Am. Med. Dir. Assoc. 2015, 16, 521-523. [CrossRef]

47. Trahair, L.G.; Kimber, T.E.; Flabouris, K.; Horowitz, M.; Jones, K.L. Gastric emptying, postprandial blood pressure, glycaemia and splanchnic flow in Parkinson's disease. World J. Gastroenterol. 2016, 22, 4860-4867. [CrossRef]

48. Trahair, L.G.; Rajendran, S.; Visvanathan, R.; Chapman, M.; Stadler, D.; Horowitz, M.; Jones, K.L. Comparative effects of glucose and water drinks on blood pressure and cardiac function in older subjects with and without postprandial hypotension. Physiol. Rep. 2017, 5, e13341. [CrossRef]

49. Vanis, L.; Hausken, T.; Gentilcore, D.; Rigda, R.S.; Rayner, C.K.; Feinle-Bisset, C.; Horowitz, M.; Jones, K.L. Comparative effects of glucose and xylose on blood pressure, gastric emptying and incretin hormones in healthy older subjects. Br. J. Nutr. 2011, 105, 1644-1651. [CrossRef]

50. Visvanathan, R.; Chen, R.; Garcia, M.; Horowitz, M.; Chapman, I. The effects of drinks made from simple sugars on blood pressure in healthy older people. Br. J. Nutr. 2005, 93, 575-579. [CrossRef]

51. Edwards, B.J.; Perry, H.M., 3rd; Kaiser, F.E.; Morley, J.E.; Kraenzle, D.; Stevenson, R.; Kreutter, D. Relationship of age and calcitonin gene-related peptide to postprandial hypotension. Mech. Ageing Dev. 1996, 87, 61-73. [CrossRef]

52. Fagius, J.; Berne, C. Increase in muscle nerve sympathetic activity in humans after food intake. Clin. Sci. 1994, 86, 159-167. [CrossRef]

53. Fagius, J.; Ellerfelt, K.; Lithell, H.; Berne, C. Increase in muscle nerve sympathetic activity after glucose intake is blunted in the elderly. Clin. Auton. Res. 1996, 6, 195-203. [CrossRef]

54. Gentilcore, D.; Nair, N.S.; Vanis, L.; Rayner, C.K.; Meyer, J.H.; Hausken, T.; Horowitz, M.; Jones, K.L. Comparative effects of oral and intraduodenal glucose on blood pressure, heart rate, and splanchnic blood flow in healthy older subjects. Am. J. Physiol. Regul. Integr. Comp. Physiol. 2009, 297, R716-R722. [CrossRef]

55. Heseltine, D.; Dakkak, M.; Woodhouse, K.; Macdonald, I.A.; Potter, J.F. The effect of caffeine on postprandial hypotension in the elderly. J. Am. Geriatr. Soc. 1991, 39, 160-164. [CrossRef]

56. Hirayama, M.; Watanabe, H.; Koike, Y.; Hasegawa, Y.; Kanaoke, Y.; Sakurai, N.; Hakusui, S.; Takahashi, A. Postprandial hypotension: Hemodynamic differences between multiple system atrophy and peripheral autonomic neuropathy. J. Auton. Nerv. Syst. 1993, 43. [CrossRef]

57. Hirayama, M.; Watanabe, H.; Koike, Y.; Kaneoke, Y.; Sakurai, N.; Hakusui, S.; Takahashi, A. Treatment of postprandial hypotension with selective alpha 1 and beta 1 adrenergic agonists. J. Auton. Nerv. Syst. 1993, 45, 149-154. [CrossRef]

58. Hoeldtke, R.D.; Dworkin, G.E.; Gaspar, S.R.; Israel, B.C.; Boden, G. Effect of the somatostatin analogue SMS-201-995 on the adrenergic response to glucose ingestion in patients with postprandial hypotension. Am. J. Med. 1989, 86, 673-677. [CrossRef]

59. Jansen, R.W.; van Lier, H.J.; Hoefnagels, W.H. Effects of nitrendipine and hydrochlorothiazide on postprandial blood pressure reduction and carbohydrate metabolism in hypertensive patients over 70 years of age. J. Cardiovasc. Pharmacol. 1988, 12 (Suppl. 4), S59-S63. [CrossRef]

60. Jansen, R.W.; Peeters, T.L.; Lenders, J.W.; van Lier, H.J.; V'T Laar, A.; Hoefnagels, W.H. Somatostatin analog octreotide (SMS 201-995) prevents the decrease in blood pressure after oral glucose loading in the elderly. J. Clin. Endocrinol. Metab. 1989, 68, 752-756. [CrossRef]

61. Jansen, R.W.; de Meijer, P.H.; van Lier, H.J.; Hoefnagels, W.H. Influence of octreotide (SMS 201-995) and insulin administration on the course of blood pressure after an oral glucose load in hypertensive elderly subjects. J. Am. Geriatr. Soc. 1989, 37, 1135-1139. [CrossRef]

62. Jansen, R.W.M.M.; Hoefnagels, W.H.L. The Influence of oral glucose loading on baroreflex function in the elderly. J. Am. Geriatr. Soc. 1989, 37, 1017-1022. [CrossRef]

63. Jones, K.L.; MacIntosh, C.; Su, Y.C.; Wells, F.; Chapman, I.M.; Tonkin, A.; Horowitz, M. Guar gum reduces postprandial hypotension in older people. J. Am. Geriatr. Soc. 2001, 49, 162-167. [CrossRef]

64. Jones, K.L.; Rigda, R.S.; Buttfield, M.D.M.; Hatzinikolas, S.; Pham, H.T.; Marathe, C.S.; Wu, T.; Lange, K.; Trahair, L.G.; Rayner, C.K.; et al. Effects of lixisenatide on postprandial blood pressure, gastric emptying and glycaemia in healthy people and people with type 2 diabetes. Diabetes Obes. Metab. 2019. [CrossRef]

65. Maruta, T.; Komai, K.; Takamori, M.; Yamada, M. Voglibose inhibits postprandial hypotension in neurologic disorders and elderly people. Neurology 2006, 66, 1432-1434. [CrossRef] 
66. Masuo, K.; Mikami, H.; Ogihara, T.; Tuck, M.L. Mechanisms mediating postprandial blood pressure reduction in young and elderly subjects. Am. J. Hypertens. 1996, 9, 536-544. [CrossRef]

67. Nair, S.; Visvanathan, R.; Gentilcore, D. Intermittent walking: A potential treatment for older people with postprandial hypotension. J. Am. Med. Dir. Assoc. 2015, 16, 160-164. [CrossRef]

68. Nair, S.; Visvanathan, R.; Piscitelli, D. Effects of postprandial blood pressure on gait parameters in older people. Nutrients 2016, 8, 219. [CrossRef]

69. Sasaki, E.; Kitaoka, H.; Ohsawa, N. Postprandial hypotension in patients with non-insulin-dependent diabetes mellitus. Diabetes Res. Clin. Pract. 1992, 18, 113-121. [CrossRef]

70. Takamori, M.; Hirayama, M.; Kobayashi, R.; Ito, H.; Mabuchi, N.; Nakamura, T.; Hori, N.; Koike, Y.; Sobue, G. Altered venous capacitance as a cause of postprandial hypotension in multiple system atrophy. Clin. Auton. Res. 2007, 17, 20-25. [CrossRef]

71. Umehara, T.; Toyoda, C.; Oka, H. Postprandial hypotension in de novo Parkinson's disease: A comparison with orthostatic hypotension. Parkinsonism Relat. Disord. 2014, 20, 573-577. [CrossRef]

72. Umehara, T.; Nakahara, A.; Matsuno, H.; Toyoda, C.; Oka, H. Predictors of postprandial hypotension in elderly patients with de novo Parkinson's disease. J. Neural. Transm. 2016, 123, 1331-1339. [CrossRef]

73. Visvanathan, R.; Horowitz, M.; Chapman, I. The hypotensive response to oral fat is comparable but slower compared with carbohydrate in healthy elderly subjects. Br. J. Nutr. 2006, 95, 340-345. [CrossRef] [PubMed]

74. Gentilcore, D.; Doran, S.; Meyer, J.H.; Horowitz, M.; Jones, K.L. Effects of intraduodenal glucose concentration on blood pressure and heart rate in healthy older subjects. Dig. Dis. Sci. 2006, 51, 652-656. [CrossRef] [PubMed]

75. Gentilcore, D.; Meyer, J.H.; Rayner, C.K.; Horowitz, M.; Jones, K.L. Gastric distension attenuates the hypotensive effect of intraduodenal glucose in healthy older subjects. Am. J. Physiol. Regul. Integr. Comp. Physiol. 2008, 295, R472-R477. [CrossRef] [PubMed]

76. Marathe, C.S.; Horowitz, M.; Trahair, L.G.; Bound, M.; Checklin, H.; Lange, K.; Rayner, C.K.; Jones, K.L. Effect of duodenal glucose load on blood pressure in type 2 diabetes. Diabetes Res. Clin. Pract. 2016, 113, 38-40. [CrossRef] [PubMed]

77. O’Donovan, D.; Feinle, C.; Tonkin, A.; Horowitz, M.; Jones, K.L. Postprandial hypotension in response to duodenal glucose delivery in healthy older subjects. J. Physiol. 2002, 540, 673-679. [CrossRef]

78. Pham, H.T.; Stevens, J.E.; Rigda, R.S.; Phillips, L.K.; Wu, T.; Hausken, T.; Soenen, S.; Visvanathan, R.; Rayner, C.K.; Horowitz, M.; et al. Effects of intraduodenal administration of the artificial sweetener sucralose on blood pressure and superior mesenteric artery blood flow in healthy older subjects. Am. J. Clin. Nutr. 2018, 108, 156-162. [CrossRef] [PubMed]

79. Trahair, L.G.; Vanis, L.; Gentilcore, D.; Lange, K.; Rayner, C.K.; Horowitz, M.; Jones, K.L. Effects of variations in duodenal glucose load on blood pressure, heart rate, superior mesenteric artery blood flow and plasma noradrenaline in healthy young and older subjects. Clin. Sci. 2012, 122, 271-279. [CrossRef]

80. Trahair, L.G.; Wu, T.; Feinle-Bisset, C.; Marathe, C.S.; Rayner, C.K.; Horowitz, M.; Jones, K.L. Comparative effects of small intestinal glucose on blood pressure, heart rate, and noradrenaline responses in obese and healthy subjects. Physiol. Rep. 2018, 6. [CrossRef]

81. Van Orshoven, N.P.; van Schelven, L.J.; Akkermans, L.M.; Jansen, P.A.; Horowitz, M.; Feinle-Bisset, C.; van Huffelen, A.C.; Oey, P.L. The effect of intraduodenal glucose on muscle sympathetic nerve activity in healthy young and older subjects. Clin. Auton. Res. 2008, 18, 28-35. [CrossRef]

82. Vanis, L.; Gentilcore, D.; Rayner, C.K.; Wishart, J.M.; Horowitz, M.; Feinle-Bisset, C.; Jones, K.L. Effects of small intestinal glucose load on blood pressure, splanchnic blood flow, glycemia, and GLP-1 release in healthy older subjects. Am. J. Physiol. Regul. Integr. Comp. Physiol. 2011, 300, R1524-R1531. [CrossRef]

83. Gentilcore, D.; Little, T.J.; Feinle-Bisset, C.; Samsom, M.; Smout, A.J.; Horowitz, M.; Jones, K.L. Role of 5-hydroxytryptamine mechanisms in mediating the effects of small intestinal glucose on blood pressure and antropyloroduodenal motility in older subjects. Am. J. Physiol. Gastrointest. Liver Physiol. 2007, 293, G692-G698. [CrossRef] [PubMed]

84. O’Donovan, D.; Feinle-Bisset, C.; Chong, C.; Cameron, A.; Tonkin, A.; Wishart, J.; Horowitz, M.; Jones, K.L. Intraduodenal guar attenuates the fall in blood pressure induced by glucose in healthy older adults. J. Gerontol. A Biol. Sci. Med. Sci. 2005, 60, 940-946. [CrossRef] [PubMed]

85. Thazhath, S.S.; Marathe, C.S.; Wu, T.; Chang, J.; Khoo, J.; Kuo, P.; Checklin, H.L.; Bound, M.J.; Rigda, R.S.; Horowitz, M.; et al. Acute effects of the glucagon-like peptide-1 receptor agonist, exenatide, on blood 
pressure and heart rate responses to intraduodenal glucose infusion in type 2 diabetes. Diabetes Vasc. Dis. Res. 2017, 14, 59-63. [CrossRef] [PubMed]

86. Vanis, L.; Gentilcore, D.; Hausken, T.; Pilichiewicz, A.N.; Lange, K.; Rayner, C.K.; Feinle-Bisset, C.; Meyer, J.H.; Horowitz, M.; Jones, K.L. Effects of gastric distension on blood pressure and superior mesenteric artery blood flow responses to intraduodenal glucose in healthy older subjects. Am. J. Physiol. Regul. Integr. Comp. Physiol. 2010, 299, R960-R967. [CrossRef] [PubMed]

87. Vanis, L.; Gentilcore, D.; Lange, K.; Gilja, O.H.; Rigda, R.S.; Trahair, L.G.; Feinle-Bisset, C.; Rayner, C.K.; Horowitz, M.; Jones, K.L. Effects of variations in intragastric volume on blood pressure and splanchnic blood flow during intraduodenal glucose infusion in healthy older subjects. Am. J. Physiol. Regul. Integr. Comp. Physiol. 2012, 302, R391-R399. [CrossRef] [PubMed]

88. Wu, T.; Trahair, L.G.; Little, T.J.; Bound, M.J.; Zhang, X.; Wu, H.; Sun, Z.; Horowitz, M.; Rayner, C.K.; Jones, K.L. Effects of vildagliptin and metformin on blood pressure and heart rate responses to small intestinal glucose in type 2 diabetes. Diabetes Care 2017, 40, 702-705. [CrossRef] [PubMed]

89. Charriere, N.; Loonam, C.; Montani, J.P.; Dulloo, A.G.; Grasser, E.K. Cardiovascular responses to sugary drinks in humans: Galactose presents milder cardiac effects than glucose or fructose. Eur. J. Nutr. 2017, 56, 2105-2113. [CrossRef]

90. Brener, W.; Hendrix, T.R.; McHugh, P.R. Regulation of the gastric emptying of glucose. Gastroenterology 1983, 85, 76-82.

91. Trahair, L.G.; Horowitz, M.; Rayner, C.K.; Gentilcore, D.; Lange, K.; Wishart, J.M.; Jones, K.L. Comparative effects of variations in duodenal glucose load on glycemic, insulinemic, and incretin responses in healthy young and older subjects. J. Clin. Endocrinol. Metab. 2012, 97, 844-851. [CrossRef]

92. Hanover, L.M.; White, J.S. Manufacturing, composition, and applications of fructose. Am. J. Clin. Nutr. 1993, 58, 724S-732S. [CrossRef]

93. Guss, J.L.; Kissileff, H.R.; Pi-Sunyer, F.X. Effects of glucose and fructose solutions on food intake and gastric emptying in nonobese women. Am. J. Physiol. Regul. Integr. Comp. Physiol. 1994, 267, R1537-R1544. [CrossRef] [PubMed]

94. Teff, K.L.; Elliott, S.S.; Tschop, M.; Kieffer, T.J.; Rader, D.; Heiman, M.; Townsend, R.R.; Keim, N.L.; D'Alessio, D.; Havel, P.J. Dietary fructose reduces circulating insulin and leptin, attenuates postprandial suppression of ghrelin, and increases triglycerides in women. J. Clin. Endocrinol. Metab. 2004, 89, 2963-2972. [CrossRef] [PubMed]

95. Yandell, R.; Baker, B.; Wittert, G.; Wishart, J.; Morris, H.; Horowitz, M.; Chapman, I. Glycemic, hormone, and appetite responses to monosaccharide ingestion in patients with type 2 diabetes. Metabolism 2002, 51, 949-957.

96. Gerrits, P.M.; Tsalikian, E. Diabetes and fructose metabolism. Am. J. Clin. Nutr. 1993, 58, 796S-799S. [CrossRef] [PubMed]

97. Hallfrisch, J.; Ellwood, K.C.; Michaelis, O.E.T.; Reiser, S.; O’Dorisio, T.M.; Prather, E.S. Effects of dietary fructose on plasma glucose and hormone responses in normal and hyperinsulinemic men. J. Nutr. 1983, 113, 1819-1826. [CrossRef]

98. Feinman, R.D.; Fine, E.J. Fructose in perspective. Nutr. Metab. 2013, 10, 45. [CrossRef] [PubMed]

99. Ter Horst, K.W.; Serlie, M.J. Fructose consumption, lipogenesis, and non-alcoholic fatty liver disease. Nutrients 2017, 9, 981. [CrossRef]

100. Wolfsdorf, J.I.; Garvey, K.C. Chapter 49-Management of diabetes in children. In Endocrinology: Adult and Pediatric, 7th ed.; Jameson, J.L., De Groot, L.J., de Kretser, D.M., Giudice, L.C., Grossman, A.B., Melmed, S., Potts, J.T., Weir, G.C., Eds.; W.B. Saunders: Philadelphia, PA, USA, 2016; pp. 854-882.

101. Sun, S.Z.; Empie, M.W. Fructose metabolism in humans-What isotopic tracer studies tell us. Nutr. Metab. 2012, 9, 89. [CrossRef]

102. Hallfrisch, J. Metabolic effects of dietary fructose. FASEB J. 1990, 4, 2652-2660. [CrossRef]

103. Mooradian, A.D.; Smith, M.; Tokuda, M. The role of artificial and natural sweeteners in reducing the consumption of table sugar: A narrative review. Clin. Nutr. ESPEN 2017, 18. [CrossRef]

104. Gallagher, C.; Keogh, J.B.; Pedersen, E.; Clifton, P.M. Fructose acute effects on glucose, insulin, and triglyceride after a solid meal compared with sucralose and sucrose in a randomized crossover study. Am. J. Clin. Nutr. 2016, 103, 1453-1457. [CrossRef] [PubMed] 
105. Gentilcore, D.; Bryant, B.; Wishart, J.M.; Morris, H.A.; Horowitz, M.; Jones, K.L. Acarbose attenuates the hypotensive response to sucrose and slows gastric emptying in the elderly. Am. J. Med. 2005, 118, 1289.e5-1289.e11. [CrossRef] [PubMed]

106. Gentilcore, D.; Vanis, L.; Wishart, J.M.; Rayner, C.K.; Horowitz, M.; Jones, K.L. The alpha ( $\alpha$ )-glucosidase inhibitor, acarbose, attenuates the blood pressure and splanchnic blood flow responses to intraduodenal sucrose in older adults. J. Gerontol. A Biol. Sci. Med. Sci. 2011, 66, 917-924. [CrossRef] [PubMed]

107. Teunissen-Beekman, K.F.; Dopheide, J.; Geleijnse, J.M.; Bakker, S.J.; Brink, E.J.; de Leeuw, P.W.; Serroyen, J.; van Baak, M.A. Differential effects of proteins and carbohydrates on postprandial blood pressure-related responses. Br. J. Nutr. 2014, 112, 600-608. [CrossRef] [PubMed]

108. Goldfein, K.R.; Slavin, J.L. Why sugar is added to food: Food science 101. Compr. Rev. Food Sci. Food Saf. 2015, 14, 644-656. [CrossRef]

109. Robayo-Torres, C.C.; Quezada-Calvillo, R.; Nichols, B.L. Disaccharide digestion: Clinical and molecular aspects. Clin. Gastroenterol. Hepatol. 2006, 4, 276-287. [CrossRef]

110. Monnard, C.R.; Grasser, E.K. Perspective: Cardiovascular responses to sugar-sweetened beverages in humans: A narrative review with potential hemodynamic mechanisms. Adv. Nutr. 2018, 9, 70-77. [CrossRef] [PubMed]

111. Breuer, H.W. Review of acarbose therapeutic strategies in the long-term treatment and in the prevention of type 2 diabetes. Int. J. Clin. Pharmacol. Ther. 2003, 41, 421-440. [CrossRef]

112. Qualmann, C.; Nauck, M.A.; Holst, J.J.; Orskov, C.; Creutzfeldt, W. Glucagon-like peptide 1 (7-36 amide) secretion in response to luminal sucrose from the upper and lower gut. A study using alpha-glucosidase inhibition (acarbose). Scand. J. Gastroenterol. 1995, 30, 892-896. [CrossRef]

113. Enç, F.Y.; Akin, L.; Turoğlu, T.; Dede, F.; Haklar, G.; Beki, N.; Yeğen, B.; Rehfeld, J.F.; Holst, J.J. Inhibition of gastric emptying by acarbose is correlated with GLP-1 response and accompanied by CCK release. Am. J. Physiol. Gastrointest. Liver Physiol. 2001, 281, G752-G763. [CrossRef]

114. Fordtran, J.S.; Soergel, K.H.; Ingelfinger, F.J. Intestinal absorption of D-xylose in man. N. Engl. J. Med. 1962, 267, 274-279. [CrossRef] [PubMed]

115. Nair, N.U.; Zhao, H. Selective reduction of xylose to xylitol from a mixture of hemicellulosic sugars. Metab. Eng. 2010, 12, 462-468. [CrossRef] [PubMed]

116. Yoshitake, J.; Ohiwa, H.; Shimamura, M.; Imai, T. Production of polyalcohol by a corynebacterium sp. Agric. Biol. Chem. 1971, 35, 905-911. [CrossRef]

117. Wolnerhanssen, B.K.; Cajacob, L.; Keller, N.; Doody, A.; Rehfeld, J.F.; Drewe, J.; Peterli, R.; Beglinger, C.; Meyer-Gerspach, A.C. Gut hormone secretion, gastric emptying, and glycemic responses to erythritol and xylitol in lean and obese subjects. Am. J. Physiol. Endocrinol. Metab. 2016, 310, E1053-E1061. [CrossRef] [PubMed]

118. Salminen, E.K.; Salminen, S.J.; Porkka, L.; Kwasowski, P.; Marks, V.; Koivistoinen, P.E. Xylitol vs glucose: effect on the rate of gastric emptying and motilin, insulin, and gastric inhibitory polypeptide release. Am. J. Clin. Nutr. 1989, 49, 1228-1232. [CrossRef] [PubMed]

119. Noda, K.; Nakayama, K.; Oku, T. Serum glucose and insulin levels and erythritol balance after oral administration of erythritol in healthy subjects. Eur. J. Clin. Nutr. 1994, 48, 286-292.

120. De Cock, P. Erythritol. In Sweeteners and Sugar Alternatives in Food Technology; John Wiley \& Sons: Hoboken, NJ, USA, 2012; pp. 213-241.

121. Flint, N.; Hamburg, N.M.; Holbrook, M.; Dorsey, P.G.; LeLeiko, R.M.; Berger, A.; de Cock, P.; Bosscher, D.; Vita, J.A. Effects of erythritol on endothelial function in patients with type 2 diabetes mellitus: A pilot study. Acta Diabetol. 2014, 51, 513-516. [CrossRef]

122. Engelking, L.R. Chapter 18-Carbohydrate structure. In Textbook of Veterinary Physiological Chemistry, 3rd ed.; Engelking, L.R., Ed.; Academic Press: Boston, MA, USA, 2015; pp. 118-123.

123. Hofman, D.L.; van Buul, V.J.; Brouns, F.J.P.H. Nutrition, health, and regulatory aspects of digestible maltodextrins. Crit. Rev. Food Sci. Nutr. 2016, 56, 2091-2100. [CrossRef]

124. Lavin, J.H.; French, S.J.; Read, N.W. Comparison of oral and gastric administration of sucrose and maltose on gastric emptying rate and appetite. Int. J. Obes. Relat. Metab. Disord. 2002, 26, 80-86. [CrossRef]

125. Murray, R.; Eddy, D.E.; Bartoli, W.P.; Paul, G.L. Gastric emptying of water and isocaloric carbohydrate solutions consumed at rest. Med. Sci. Sports Exerc. 1994, 26, 725-732. [CrossRef] 
126. Shankar, P.; Ahuja, S.; Sriram, K. Non-nutritive sweeteners: Review and update. Nutrition 2013, 29, $1293-1299$. [CrossRef] [PubMed]

127. Police, S.B.; Harris, J.C.; Lodder, R.A.; Cassis, L.A. Effect of diets containing sucrose vs. D-tagatose in hypercholesterolemic mice. Obesity 2009, 17, 269-275. [CrossRef] [PubMed]

128. Roy, S.; Chikkerur, J.; Roy, S.C.; Dhali, A.; Kolte, A.P.; Sridhar, M.; Samanta, A.K. Tagatose as a potential nutraceutical: Production, properties, biological roles, and applications. J. Food Sci. 2018, 83, 2699-2709. [CrossRef] [PubMed]

129. Donner, T.W.; Wilber, J.F.; Ostrowski, D. D-tagatose, a novel hexose: Acute effects on carbohydrate tolerance in subjects with and without type 2 diabetes. Diabetes Obes. Metab. 1999, 1, 285-291. [CrossRef] [PubMed]

130. Ensor, M.; Williams, J.; Smith, R.; Banfield, A.; Lodder, R.A. Effects of three low-doses of D-tagatose on glycemic control over six months in subjects with mild type 2 diabetes mellitus under control with diet and exercise. J. Endocrinol. Diabetes Obes. 2014, 2, 1057. [PubMed]

131. Lu, Y.; Levin, G.V.; Donner, T.W. Tagatose, a new antidiabetic and obesity control drug. Diabetes Obes. Metab. 2008, 10, 109-134. [CrossRef] [PubMed]

132. Ensor, M.; Banfield, A.B.; Smith, R.R.; Williams, J.; Lodder, R.A. Safety and efficacy of D-tagatose in glycemic control in subjects with type 2 diabetes. J. Endocrinol. Diabetes Obes. 2015, 3, 1065.

133. Little, T.J.; Gopinath, A.; Patel, E.; McGlone, A.; Lassman, D.J.; D'Amato, M.; McLaughlin, J.T.; Thompson, D.G. Gastric emptying of hexose sugars: Role of osmolality, molecular structure and the CCK(1) receptor. Neurogastroenterol. Motil. 2010, 22, 1183-1190.e314. [CrossRef] [PubMed]

134. Wu, T.; Zhao, B.R.; Bound, M.J.; Checklin, H.L.; Bellon, M.; Little, T.J.; Young, R.L.; Jones, K.L.; Horowitz, M.; Rayner, C.K. Effects of different sweet preloads on incretin hormone secretion, gastric emptying, and postprandial glycemia in healthy humans. Am. J. Clin. Nutr. 2012, 95, 78-83. [CrossRef]

135. Hough, L. Sucrose, sweetness, and sucralose. Int. Sugar J. 1989, 91, 23-37.

136. John, B.A.; Wood, S.G.; Hawkins, D.R. The pharmacokinetics and metabolism of sucralose in the mouse. Food Chem. Toxicol. 2000, 38 (Suppl. 2), S107-S110. [CrossRef]

137. Wood, S.G.; John, B.A.; Hawkins, D.R. The pharmacokinetics and metabolism of sucralose in the dog. Food Chem. Toxicol. 2000, 38 (Suppl. 2), S99-S106. [CrossRef]

138. Roberts, A.; Renwick, A.G.; Sims, J.; Snodin, D.J. Sucralose metabolism and pharmacokinetics in man. Food Chem. Toxicol. 2000, 38 (Suppl. 2), S31-S41. [CrossRef]

139. Ma, J.; Bellon, M.; Wishart, J.M.; Young, R.; Blackshaw, L.A.; Jones, K.L.; Horowitz, M.; Rayner, C.K. Effect of the artificial sweetener, sucralose, on gastric emptying and incretin hormone release in healthy subjects. Am. J. Physiol. Gastrointest. Liver Physiol. 2009, 296, G735-G739. [CrossRef]

140. Kazmi, S.A.J.; Khan, A.N.; Naqib, M.; Munir, T.A. Comparison of acute effects of sucralose, aspartame and acesulfame potassium on pulse, blood pressure, and blood glucose levels in young healthy adults. World J. Pharm. Pharm. Sci. 2017, 7, 60-69.

141. Wu, T.; Bound, M.J.; Standfield, S.D.; Bellon, M.; Young, R.L.; Jones, K.L.; Horowitz, M.; Rayner, C.K. Artificial sweeteners have no effect on gastric emptying, glucagon-like peptide-1, or glycemia after oral glucose in healthy humans. Diabetes Care 2013, 36, e202-e203. [CrossRef]

142. Brown, R.J.; Walter, M.; Rother, K.I. Ingestion of diet soda before a glucose load augments glucagon-like peptide-1 secretion. Diabetes Care 2009, 32, 2184-2186. [CrossRef]

143. Steinert, R.E.; Frey, F.; Töpfer, A.; Drewe, J.; Beglinger, C. Effects of carbohydrate sugars and artificial sweeteners on appetite and the secretion of gastrointestinal satiety peptides. Br. J. Nutr. 2011, 105, 1320-1328. [CrossRef]

144. Little, T.J.; Gupta, N.; Case, R.M.; Thompson, D.G.; McLaughlin, J.T. Sweetness and bitterness taste of meals per se does not mediate gastric emptying in humans. Am. J. Physiol. Regul. Integr. Comp. Physiol. 2009, 297, R632-R639. [CrossRef]

145. Samuel, P.; Ayoob, K.T.; Magnuson, B.A.; Wölwer-Rieck, U.; Jeppesen, P.B.; Rogers, P.J.; Rowland, I.; Mathews, R. Stevia leaf to stevia sweetener: Exploring its science, benefits, and future potential. J. Nutr. 2018, 148, 1186S-1205S. [CrossRef]

146. Jorge, K. SOFT DRINKS|Chemical Composition. In Encyclopedia of Food Sciences and Nutrition, 2nd ed.; Caballero, B., Ed.; Academic Press: Oxford, NY, USA, 2003; pp. 5346-5352. 
147. Anton, S.D.; Martin, C.K.; Han, H.; Coulon, S.; Cefalu, W.T.; Geiselman, P.; Williamson, D.A. Effects of stevia, aspartame, and sucrose on food intake, satiety, and postprandial glucose and insulin levels. Appetite 2010, 55, 37-43. [CrossRef]

148. Gregersen, S.; Jeppesen, P.B.; Holst, J.J.; Hermansen, K. Antihyperglycemic effects of stevioside in type 2 diabetic subjects. Metabolism 2004, 53, 73-76. [CrossRef]

149. Pereira, R.M.; Secaf, M.; de Oliveira, R.B. Effects of different sweeteners on incretin hormone secretion, gastric emptying, intragastric distribution and postprandial glycemia in healthy humans. FASEB J. 2013, 27, 1160-1161. [CrossRef]

150. Hsieh, M.H.; Chan, P.; Sue, Y.M.; Liu, J.C.; Liang, T.H.; Huang, T.Y.; Tomlinson, B.; Chow, M.S.; Kao, P.F.; Chen, Y.J. Efficacy and tolerability of oral stevioside in patients with mild essential hypertension: A two-year, randomized, placebo-controlled study. Clin. Ther. 2003, 25, 2797-2808. [CrossRef]

151. Chan, P.; Tomlinson, B.; Chen, Y.J.; Liu, J.C.; Hsieh, M.H.; Cheng, J.T. A double-blind placebo-controlled study of the effectiveness and tolerability of oral stevioside in human hypertension. Br. J. Clin. Pharmacol. 2000, 50, 215-220. [CrossRef]

152. Maki, K.C.; Curry, L.L.; Carakostas, M.C.; Tarka, S.M.; Reeves, M.S.; Farmer, M.V.; McKenney, J.M.; Toth, P.D.; Schwartz, S.L.; Lubin, B.C.; et al. The hemodynamic effects of rebaudioside A in healthy adults with normal and low-normal blood pressure. Food Chem. Toxicol. 2008, 46, S40-S46. [CrossRef]

153. Barriocanal, L.A.; Palacios, M.; Benitez, G.; Benitez, S.; Jimenez, J.T.; Jimenez, N.; Rojas, V. Apparent lack of pharmacological effect of steviol glycosides used as sweeteners in humans. A pilot study of repeated exposures in some normotensive and hypotensive individuals and in Type 1 and Type 2 diabetics. Regul. Toxicol. Pharmacol. 2008, 51,37-41. [CrossRef]

154. O'Brien-Nabors, L. Alternative Sweeteners; CRC Press: Boca Raton, FL, USA, 2016.

155. Khan, R.; Aroulmoji, V. Low calorie high-intensity sweeteners. Int. J. Adv. Sci. Eng. 2018, 5, $934-947$. [CrossRef]

(C) 2019 by the authors. Licensee MDPI, Basel, Switzerland. This article is an open access article distributed under the terms and conditions of the Creative Commons Attribution (CC BY) license (http://creativecommons.org/licenses/by/4.0/). 